\title{
Procedures and criteria to develop and evaluate household sustainable consumption indicators
}

\author{
Sandra Caeiro ${ }^{\mathrm{a}, *}$, Tomás B. Ramos ${ }^{\mathrm{b}, 1}$, Donald Huisingh ${ }^{\mathrm{c}, 2}$ \\ ${ }^{a}$ IMAR - Institute of Marine and Environmental Research and Departmento de Ciências e Technologia, Universidade Aberta, Rua Escola Politécnica, \\ $n^{\circ}$ 141-147, 1269-001 Lisboa, Portugal \\ ${ }^{\mathrm{b}}$ CENSE - Center for Environmental and Sustainability Research, Departamento de Ciências e Engenharia do Ambiente, Faculdade de Ciências e Tecnologia, \\ Universidade Nova de Lisboa, Campus da Caparica, 2829-516 Caparica, Portugal \\ ${ }^{\mathrm{c}}$ Institute for a Secure and Sustainable Environment, University of Tennessee, 311 Conference Center Building, Knoxville, TN 37996-4134, USA
}

\section{A R T I C L E I N F O}

\section{Article history:}

Received 12 April 2011

Received in revised form

24 December 2011

Accepted 26 December 2011

Available online 8 January 2012

\section{Keywords:}

Households

Sustainable consumption

Indicators

Evaluation criteria for sustainable

consumption

Integrated approach to evaluate household

consumption

Stakeholder engagement

\begin{abstract}
A B S T R A C T
Communication about very complex problems like household sustainable consumption in simple terms is still a major challenge. Despite the diversity of tools to measure household consumption, clearer indicators are needed to more effectively communicate with the general public. The main objective of this research was to develop an approach to define the main procedures and criteria to built household sustainable consumption assessment tools based on indicator sets. A review of available household sustainable consumption assessment metrics and related initiatives was conducted; this included a comparative analysis of the different approaches. The review revealed that the majority of these initiatives are focused upon specific domains (e.g. energy or waste), but none used an integrated approach in the sustainable consumption domains. Furthermore, it was found that few methods used indicators to measure and assess household sustainable consumption. Principal components and a checklist of key good-practice factors that a household sustainable consumption indicator system should include were developed. Due to the need to communicate effectively, to engage stakeholders and to address the complexity involved in the measurement and assessment of household sustainable consumption, the proposed integrated approach was designed to evaluate household sustainable consumption.
\end{abstract}

(c) 2012 Elsevier Ltd. All rights reserved.

\section{Introduction}

Economic and consumption growths have been closely linked and have followed similar patterns. In other words, as people become wealthier, in most cases, they increase their consumption of goods and services. The projected economic growth of $2.4 \%$ per year in the EU-25 between 2000 and 2030 will be accompanied by similar growth in consumption (EEA, 2005). Evolving material intensive consumption patterns and lifestyles present a major challenge to sustainability (Druckman et al., 2008). It has become increasingly clear that sustainable economies must be built upon concepts and approaches of Sustainable Consumption (SC) (Clark, 2007; UNEP, 2011). One of the first definitions of SC is included in the Oslo Declaration, which stated, "SC is the use of goods and

\footnotetext{
* Corresponding author. Tel.: +351 213916300; fax: +351 213916517.

E-mail addresses: scaeiro@uab.pt (S. Caeiro), tabr@fct.unl.pt (T.B. Ramos), donaldhuisingh@comcast.net (D. Huisingh).

1 Tel: +351 212948397.

2 Tel.: +1 8656924066
}

services that respond to basic needs and bring a better quality of life while minimizing the use of natural resources, toxic materials and emissions of waste and pollutants over the life cycle, so as not to jeopardise the needs of future generations" (OECD, 1997). Recently, multiple authors have emphasised that consumption should be decoupled from economic growth and material resource consumption; this perspective envisions that monetary growth should be 'decoupled' from growth in physical throughputs and environmental impacts and that prosperity, within the ecological limits of a finite planet, without growth is possible (Jackson, 2007, 2009; UNEP, 2011).

The paradigmatic propositions of degrowth are that economic growth is not sustainable and that human progress without economic growth is possible. Sustainable degrowth can be seen as an equitable downscaling of production and consumption that increases human well being and enhances ecological conditions at the local and global level, in the short and long term (Schneider et al., 2010). Within the concept of sustainable degrowth, one new economics model introduces alternatives to individual purchasing actions, where innovation is driven by collective action 
far beyond the action of price signals. Progress is to be measured by new criteria, such as community-building, collective action, and construction of new infrastructures of provision, in which wellbeing is not wholly tied to consumption (Ehrenfeld, 2010; Cohen et al., 2010).

The European Union (EU) is placing increasing emphasis on sustainable use and management of natural resources, especially since the adoption in 2001 of the EU Sustainable Development Strategy and the Sixth Environmental Action Programme (EEA, 2005). Additionally, the Johannesburg Summit in 2002 recommended the development and promotion of the "Marrakech process" or the 10-Year Framework of Programmes on Sustainable Consumption and Production (SCP) in which the United Nations Environment Program (UNEP) and the UN Department of Economic and Social Affairs (UNDESA) are the leading agencies. This global, multi-stakeholder process, has several Task Forces, which provide a forum for developing countries for promoting implementation of SCP at national and international levels (UNEP, 2011). The 2002 United Nation's Summit also highlighted the need to address the following SC objectives: i) to develop awareness-raising programmes, particularly for youth, through education, consumer information, and advertising; ii) to develop and adopt consumer information tools, for better household SC behaviours and attitudes (Clark, 2007).

In 2008 the European Commission published their SCP and Sustainable Industrial Policy Plan, in which a range of policies at the EU and national levels are encouraged to develop and use resource efficient and eco-friendly products and to raise consumer awareness about the ecological and economic benefits of doing so. The proposals on SCP included in this Plan complement the policy instruments and provide measures where gaps existed (COM, 2008).

Household consumption forms an important part of the production-consumption chain, because consumers make the final choice of the goods and services they consume, and their lifestyles determine how they influence sustainability practices. Individuals/ families should be seen as part of the solution, and not simply as part of the problem, in promoting SC because their values and participation must be the basis for individual and public action (Comim et al., 2007; UNEP, 2011; Cohen et al., 2010).

A simple recipe to realize SC is impossible or ethically disputable. Nevertheless, the empirical findings support many of the observations about unsustainable consumption, notably that it is generally positively related to income, age, family size, education and high-status jobs (Ferrer-i-Carbonell and Van Den Bergh, 2004) and household expenditures (Kerkhof et al., 2009b).

Understanding household consumption patterns is fundamentally about understanding human behaviour. Important factors that drive our consumption include growing incomes, globalization of the economy, technological breakthroughs (such as the Internet and mobile phones), pervasive advertising, decreasing household sizes and an ageing population. At the same time, the growing number of goods and services we consume often offsets the efficiency gains we achieved through, for example, improved production technologies and processes. According to Jevons' Paradox, technological change is the main cause of increased production and consumption (Alcott, 2005; Polimeni et al., 2008) and as a result, environmental pressures are increasing. At the household level, housing, food and drink and mobility have the greatest environmental impacts in terms of emissions of greenhouse gases, acidifying and ozone-depleting substances as well as resource and energy use (EEA, 2005, 2010; Tukker et al., 2010a; UNEP, 2011). Those household activities are strongly related with lifestyles and daily live routines that determine household consumption behaviours and practices and are decisive for the energy and water consumption and waste production. These routines pertain to comfort (heating and lighting the home), hygiene (bathing, washing clothes and dishes), cooking (storing food and preparing meals) and communication, entertainment, education and transportation. As these routines are developed they become embedded within the social, cultural and physical infrastructure; consequently, if we are to seek to make changes, we need to addresses the resistance to change due to social and cultural embeddedness. This perspective is essential in seeking to make changes in household SCP because it is contextualised upon the importance of social and cultural aspects in the consumption and use phases of technology (Gram-Hanssen, 2008). Lifestyle has been used in several research studies to understand and explain different consumption patterns, but these studies have encountered problems in linking actors' environmental awareness and measured consumption, and then relating this to lifestyles theories (Jensen, 2008).

Household Sustainable Consumption (HSC) should integrate various disciplines in order to more fully understand the driving forces of consumer behaviour and to develop policy instruments designed to help change consumer behaviour (Kletzan et al., 2002). Such efforts should also be linked with environmental innovations in ecologically improved housing, which are strongly related with environmental and financial advantages (Hal, 2007).

Behavioural changes and innovation strategies have a strong potential to mitigate the environmental impacts of household consumption (Brown and Vergragt, 2008; Tukker et al., 2010b; Cohen et al., 2010). The dynamics of the relationships between consumer behaviours (and expenditures) and their associated environmental impacts have been researched to some extent during the past decade. However, our knowledge is incomplete of effective ways to promote and support HSC through behaviour changes. In addition the state of knowledge is far less with respect to questions pertaining to the role of policy measures to stimulate sustainable lifestyles, to facilitate sustainable consumer behaviours, and to foster the development and usage of sustainable systems of production and consumption (OECD, 2008a; Tukker et al., 2010a; Cohen et al., 2010).

Additionally, policy measures, consumer education and information are essential to achieving SC patterns that make it feasible for consumers/citizens to act sustainably, and to adopt more SCP patterns (EEA, 2010). Promoting more sustainable household consumption practices requires a multi-stakeholder approach, including public policy, market innovation, NGO mobilisation of consumer groups and voluntary initiatives. An educational, learning and information-rich environment that motivates and enables consumer actions is required to create a framework for HSC (OECD, 2002; Tukker et al., 2010b).

The Marrakech Process Progress Report, published in 2011 (UNEP, 2011), outlined the following key outputs for SCP: a. projects on education and lifestyles, b. preparation and usage of a global surveys on sustainable lifestyles, c. development of regional and national SCP strategies and action plans, d. implementation of sustainable public procurement at national and local levels, e. usage of campaigns and policy recommendations for sustainable tourism, and $\mathrm{f}$. implementation of best practices for sustainable building and construction.

OECD (2008a) published a review of empirical evidence that characterized the determinants of household environmental behaviour in five key areas of environmental policy: waste generation and recycling, personal transport choices, residential energy use, food consumption and domestic water use. These categories can be the bases for determining how to improve the effectiveness and efficiency of environmental policies that affect household consumption, while simultaneously addressing social concerns. 
The main objective of the research for this paper was to develop an approach to define the main steps and criteria to build and evaluate HSC upon indicator sets.

\section{An overview of household sustainable consumption metrics}

Despite the diversity of tools to measure household consumption, there is a lack of indicator tools to assist families to make HSC decisions. Properly developed and used, indicators have the potential for effective communication to and usage by the general public. Indicators are special signs that convey "value added messages" in a simplified and useful manner to the citizens. An indicator can be derived from a single variable to reflect some attribute or from an aggregation of several variables.

Indicator sets, in particular, Sustainable Development Indicators (SDIs) are being used to collect, process, and use information with the following objectives: i) to help decision-makers to make better decisions, ii) to guide smarter policy choices, iii) to measure progress, and iv) to monitor feedback mechanisms, as emphasised in the United Nations Conference on Environmental and Development, held in Rio de Janeiro in 1992 (Agenda 21, Chapter 40). Although the adoption of indicators helps in the analysis of many types of information, in-depth evaluations are essential in order to develop proper measures to drive policies, through the implementation of concrete and effective HSC improvement plans. The policies should be developed based upon assessments of the strengths and weaknesses identified by the indicators (Scipioni et al., 2008).

There has been a proliferation of indicators for sustainability, ranging from environmental profiles and trends to a wide variety of quality of life measures. But proliferation makes the choice of indicators difficult for policy-making and for civil society actions. Although there is not full agreement within the research community, some authors are convinced that general SDIs are not applicable to SC and production. Most international agencies and institutions have responded to this problem of choosing indicators based upon large databases, assuming that the availability of data would encourage governmental policy makers to incorporate different indicators to assist families in making their HSC decisions (Comim et al., 2007). According to them, the two most important roles of SC indicators should be: i) educational, for stimulating communication of SC results that can be used as inputs in participatory processes for building accountability to concrete targets and ii) managerial, for informing policy interventions and guiding planning decisions.

Indicators permit the combination of different approaches such as input-output analysis, environmental statistics, questionnaire surveys and household budget data, thereby, facilitating improved understanding of the influence of various household characteristics on environmental degradation (Munksgaard et al., 2005). According to the 10-Year Framework of Programmes on SCP, indicators are important tools for measuring progress of SC at local, regional or national levels (UNDESA/UNEP, 2010).

A large number of environmental assessment methods are now available to help assess the sustainability of products, processes and of lifestyles, but few studies have been undertaken to compare the effectivity of these different tools (Huijbregts et al., 2008). According to OECD (2008a), there is an urgent need for 'common frameworks' to be used in different countries to collect comparable primary data on household environmental behaviour and individual responses to environmental policies; this is especially true because the studies that have been done to date used very different methodological approaches, therefore, the findings are not directly comparable.
Table A1, in the appendix of this paper, presents an overview of studies that measure or assess household SC, as examples of this type of work that has been done throughout the world. Table A1 reviews the studies aims/scopes, methodologies, domains, direct use or development of indicator [yes/no] and also provides additional qualitative reflections on the diverse studies that were studied.

The majority of the studies are about consumption patterns regarding one specific domain of HSC (like energy consuming and carbon dioxide emissions, water, waste, food and resources use) or two domains (e.g. energy plus water plus waste). As reported by Munksgaard et al. (2005), many studies about HSC consider only one or a few environmental pressures such as energy consumption or $\mathrm{CO}_{2}$ emissions.

Different methodologies were/are used to measure or to assess HSC. They vary from questionnaire surveys, input-output analyses, indicators and other mathematical and statistical models, like multivariate statistics (Table A1). There are several works that used questionnaire surveys complemented in some cases with interviews to improve the depth of the data that were collected (e.g. Fahy and Davies, 2007 or Baker and Rylatt, 2007). This collecting method is most related with understanding consumer sustainable (or unsustainable) behaviour. The input-output analysis was also used within HSC, especially within the study of the domain waste (e.g. Takase et al., 2005) or energy (Munksgaard et al., 2005).

A number of international organizations as well as some European governments have developed sets of indicators for SCP, as part of broader indicator sets for environment and sustainable development that included: a. household materials, b. water and electricity consumption, c. generation of household waste, d. energy consumption and $\mathrm{CO}_{2}$ emissions from personal transport, e. share of overweight or obese people, e. extent of green public procurement, and f. ecolabel awards by product group. (OECD, 2008b). The United Nations Department of Economic and Social Affairs (UN/DESA, 1998) published a set of indicators as an important element of United Nations Commission on Sustainable Development (CSD) work program of indicators for sustainable development. Seventeen SCP indicators were selected as a core set, which cover four key resources and five consumption clusters. Within these indicators there are indicators that are specific or applicable for HSC in domains such as energy, materials, water, land, mobility, consumer goods and services, building and housekeeping, food, recreation. The Indicators for monitoring the EU Sustainable Development Strategy include a theme about SCP in which some indicators are applicable to HSC (CEC, 2005). Additionally, the European Environment Agency included eight household consumption indicators and fact sheets within the EEA indicator's list Europe's environment 275 indicators. These indicators include domains such as water, wastewater, energy, expenditures and products (EEA, 2011).

The OECD (1999) was the first institution to develop a specific indicator set for HSC. That indicator set is based upon the Pressure-State-Respond indicator framework and distinguishes three themes: i) environmentally significant consumption trends and patterns; ii) interactions between consumption patterns and the environment; iii) economic and policy aspects. The proposed twenty-one indicators are grouped into general trends (economic and socioeconomic) and by major consumption activities: i) economic trends, ii) socioeconomic trends, iii) transport and communication, iv) consumption of durable and non-durable goods, including food, v) recreation and tourism and vi) housing related energy and water use.

After the OECD indicator set was published, Lorek and Spangenberg (2001), proposed a fourteen indicator set for environmentally sustainable household consumption. First, the authors established a conceptual array of household consumption 
indicators. As a second step, a set of indicators for sustainable household consumption was derived, based on an actor-centred approach. Their proposal was based on calculations of resource consumption as the key driving force of environmental problems, and an estimate of actors' influence. The limited and thus easily communicable number of indicators resulted from the identification of dominating factors of resource consumption, which were covered by one or a few indicators. According to the authors, it is possible to adapt the system of indicators to the diversity of country size infrastructure, climate, heating, among others. Three consumption clusters were identified in the research for this paper, as priority fields for action by households: 1 . construction and housing, 2. food/nutrition and 3. transport (Spangenberg and Lorek, 2002). In spite of the large amount of work involved in these initiatives, the indicator proposals have been largely centred in the environmental dimensions of sustainability; furthermore, some of them are under revision and/or are being up-graded.

Other HSC indicator sets address the operational level of household consumption (inputs as energy and materials and outputs as waste or used materials), in a specific domain like energy, food, water or waste (e.g. Wood and Newborough, 2003 - energy consumption indicators; OECD, 2001 - food consumption indicators), or pertain to the strategic level of household consumption, like quality of life, behaviour, routines or actions (e.g. Jensen, $2008-$ lifestyle indicators based on water and energy consumption and Katz-Gerro and Talmud, 2005 - stratification indicators to predict ability in estimating consumption behaviour based on household expenditures). Other researchers used computerised models to calculate a single HSC indicator (e.g. Nansai et al., 2007, proposed a simple indicator for HSC by calculating the optimal household patterns using a liner programming model that focussed directly upon the environmental burdens to be minimized).

Energy usage is a central element of HSC of green consumer's efforts to reduce their GHG emissions. However, although households show certain tendencies, there is no clear indicator that always identified green consumers. For example Girod and Haan (2009), studied the GHG reduction potential for changes in consumption patterns in Swiss household consumption; they found high GHG emitters who bought organic food, lived in car-free households and were vegetarian (according to this study, highemitters differ from the low-emitters mainly due to differences in heating, electricity use, and air-travel usage). These results showed that it is very important that an HSC indicator system considers and integrates several domains and multiple levels of analysis.

Some HSC researchers have addressed ecological and carbon footprints, to study the HSC behaviour by using a set of aggregated metrics (e.g. Holden, 2004; Wiedmann et al., 2005; Sutcliffe et al., 2008; Druckman and Jackson, 2009). However, as stated by Munksgaard et al. (2005), the major drawback of this type of approach is that it covers a limited scope of environmental "stressors"/domains: energy consumption, land use, food, and $\mathrm{CO}_{2}$ emissions. This does not allow a thorough and rigorous assessment of a certain domain. In addition the Ecological Footprint does not provide an overview of each domain separately so the families would not know what changes should be implemented, what mistakes are being made and how to correct them. Nevertheless, it makes it possible to benchmark against sustainability thresholds, which help in identifying and communicating over-consumption. It can also be used in combination with other indicators (EEA, 2010).

\section{Methodological approach to HSC indicators}

Despite the existence of some initiatives that propose HSC indicator sets, as presented in Section 2, the majority are primarily sectoral, focussing only upon one thematic issue or are mainly focussed upon the environmental dimensions of sustainability. Those initiatives were not designed to provide a coherent, stepby-step, framework to support guidance approaches for the development and evaluation of HSC systems as whole processes, that address multiple components and actors, and which are not simply designed to produce an isolated set of indicators.

In this research, an approach for the development of a conceptual framework to build and evaluate HSC indicators was developed with the objective to determine how to effectively put such indicators into practice (Fig. 1). This framework was designed, to be applied to spatially aggregated household's initiatives, at the national, regional or local levels or to individual householder's initiatives, in order to support the process of indicator development and evaluation of the assessment procedures and of the outcomes.

After this research, to support the effective application of the proposed methodological approach a "practitioner's guidebook", using case study demonstrations, will be developed. This guidebook will clarify how to fill in, to implement and to amend the different components, with regard to when, how and who implements or uses the indicators. Consequently, the researchers identified the main principles, variables and flows of HSC indicator systems, including the governance, management and technical components, to provide practical guidance for HSC indicator users and stakeholders to achieve improvements in their sustainability attitudes and behaviours.

The developers of this method assumed that household consumption assessment processes, and their measurement tools, should be centred on the entire household system, by taking into account the different materials, energy and non-material flows, practices and behaviours. Sustainability evaluation systems should avoid the issues by category compartmentalization, which leads to the division of household economic, environmental, institutional/ governance and social aspects. It is the convergence within the different domains that ultimately define whether the 'system' is sustainable. Sustainability consumption evaluation requires integrated approaches, based on the weighting of the different sustainability domains, which are designed to help to define whether a system is sustainable or not. As stated earlier, there is no guarantee that sustainable conditions in one domain (e.g. energy consumption) will be the same for other domains (e.g. waste production, species diversity losses, toxics use reduction).

This approach is supported by key components, including stakeholder engagement, and building upon their views and opinions along the entire process. This cross fertilisation process should include key-stakeholders (experts and non-experts), in particular governmental institutions, non-governmental organizations, local communities and residents/family's representatives', private operator's and service providers, academics and research institutions. Such collaborative and participative activities have a central role in the development, implementation, operation and follow-up of the HSC assessment system. Such participative processes could use various techniques, in particular focus groups, interviews, questionnaires, and visualization techniques such as drawing and mapping and Public Participation using Geographic Information System (PPGIS). PPGIS as a tool to visualize, process and acquire data in order to ensure more transparent and efficient participation. Furthermore, the results of using the indicators to monitor progress should be used to inform all stakeholders.

The proposed framework should be used as a flexible and dynamic system that can be tailored to different situations or conditions. The degree of required adaptation will be based upon user's needs or constrains, including particular features and characteristics of a given case, or data limitations and drawbacks. Furthermore, as the framework is implemented, its performance must be monitored on an on-going manner with a transparent, 


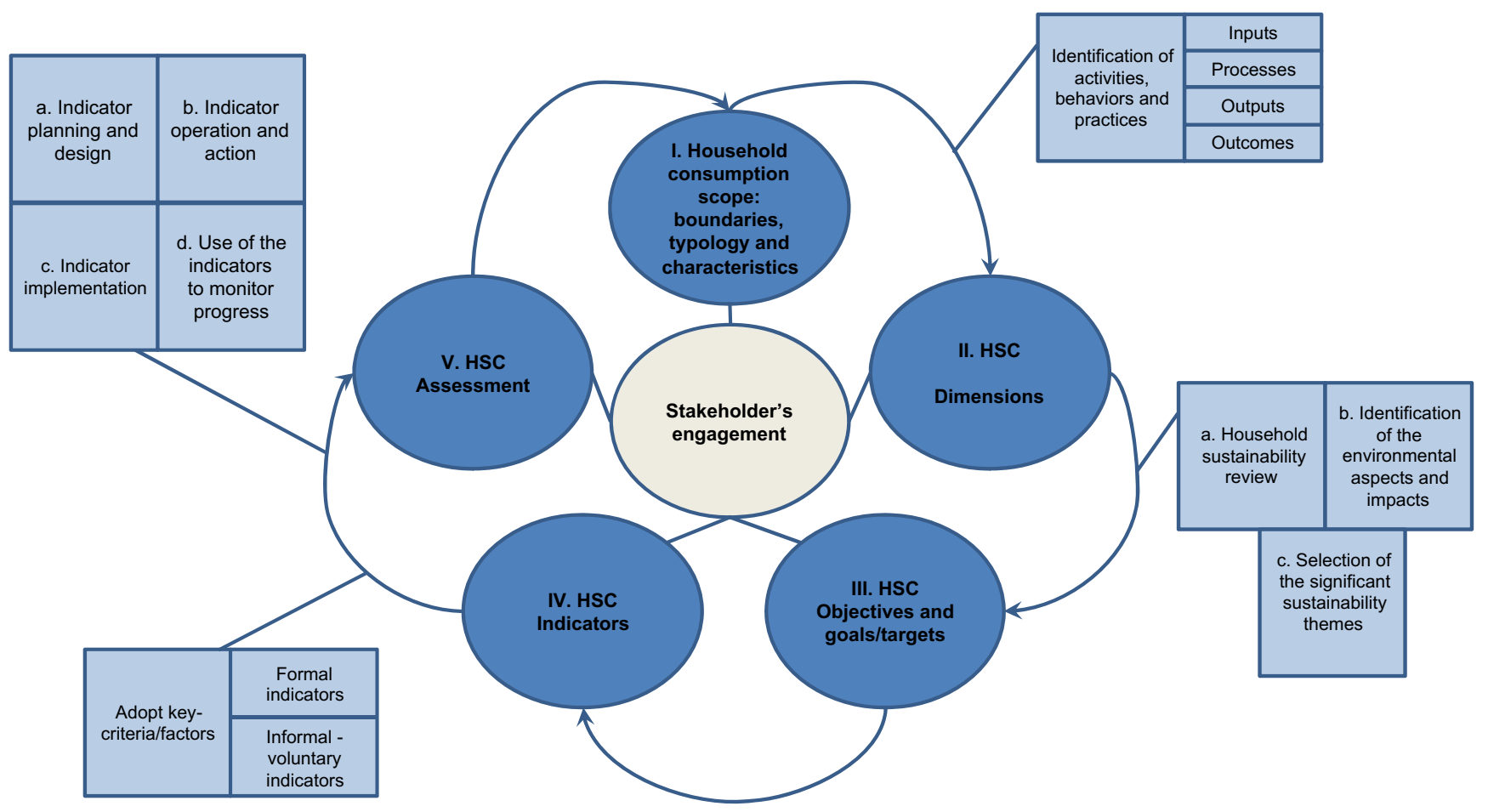

Fig. 1. A framework for the development of household SC indicators.

accurate and valid method. The results of on-going monitoring of effectivity of the framework should be shared with all stakeholders. Furthermore, improvements in the system should be integrated and used cybernetically from the beginning of the entire multi-year process. The design of the HSC indicator set should include the following main steps:

\subsection{Household consumption scope: boundaries, typologies and characteristics}

Identification of the household consumption scope, definition of the boundaries of the consumption areas that will be included at the operational level (typical inputs, outputs measures and related practices or actions) and strategic level (household consumption policies, planning/programming and behaviours). Household activity characteristics should be used to guide the analysis of inputs, processes, outputs and, when possible, the outcomes; this would include a clear description of household facilities including type and/or size (e.g. apartment and area) and buildings, land area owned, residents, materials and equipment used;

\subsection{HSC dimensions}

An initial review of the Strengths, Weaknesses, Opportunities and Threats (SWOT) of household consumption should be conducted. A checklist survey similar to the approach used in the initial environmental review conducted to implement an Environmental Management System could be complemented with an SWOT analysis to help researchers and others to gain insights into the system's potential functionalities. This review could be performed using pre-designed checklists of typical environmental and sustainability questions for each HSC target level (individual households or spatially aggregated at local/regional/national) and could also be used to design and test simple household "eco-maps" for easy graphical representation of the spatial incidence of the identified issues.
Such checklists can enable the integration of sustainability considerations into household's policies, and operations. Based upon this survey, the following items should be identified:

Significant environmental and sustainability "aspects"/ pressures: This refers to specific environmental and sustainability pressures such as water, materials and energy consumption, pollutant emissions, waste disposal or land use patterns produced by the household activities, products and services (or parts);

$\bigcirc$ Significant environmental and sustainability impacts: This refers to human effects on the state of the environment and sustainability systems caused by the pressures, which are relevant for human health and/or for the ecosystem's proper functioning. It should be stressed that the term significant carries no statistical meaning when used in this context; this term refers to criteria such as the importance of effects on a human receptor or on natural resources, or to the degree of compliance with an environmental standard or goal.

At the end, the identification of the more significant HSC domains or themes should be used to address the scope of activities outlined in the previous step. The selected sustainability themes, included in the social, economic, environmental and governance/institutional pillars, will reflect the issues that are most affected by the household driving forces (understood as the social needs that require the existence of a given household's activities) - the activities, behaviours and practices. The domains should also be built upon nontraditional aspects of sustainability (Ramos, 2009), such as goal and target/limit uncertainties, ethics, cultural dimensions, aesthetics and general non-material values (e.g. solidarity, compassion, mutual help).

\subsection{HSC objectives and targets}

The definition of the main objectives and targets for each HSC domain or theme, are to reflect upon the needs, desires, sensibilities 


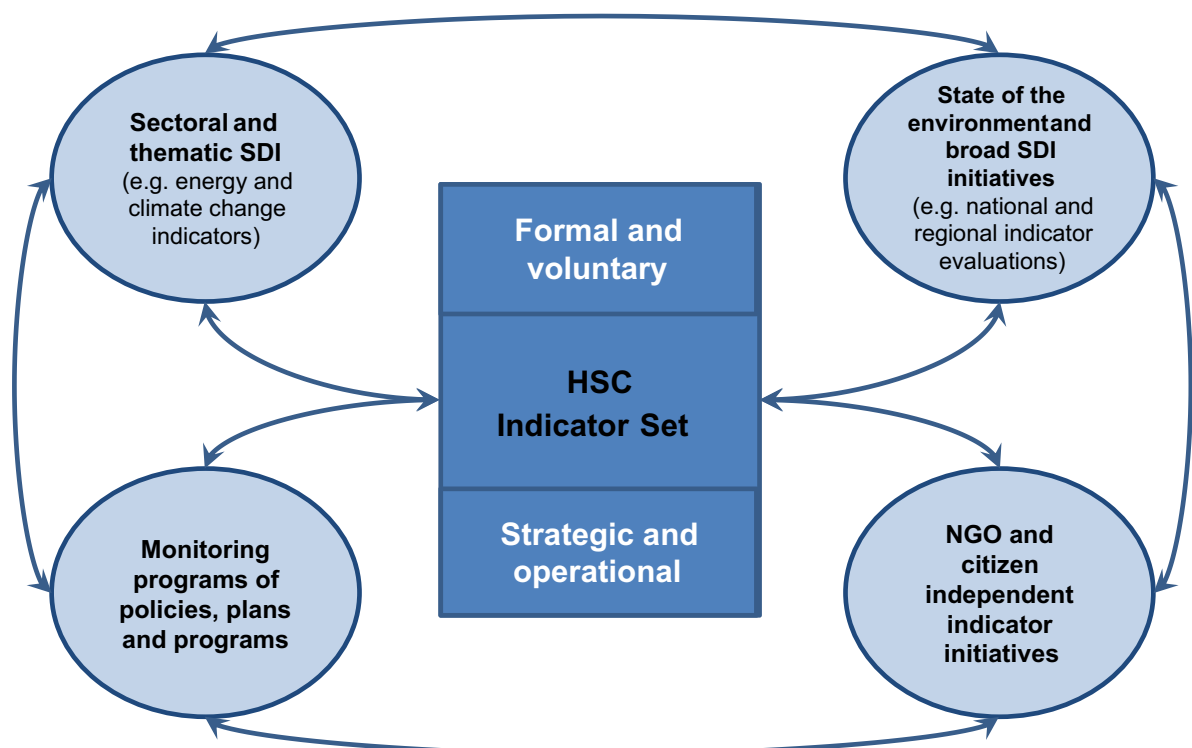

Fig. 2. Relationship of the HSC indicator set with existent "external" sustainability indicators systems or other indicator related initiatives.

and aspirations of the householders. The objectives could defined or adapted based upon the main relevant available strategic instruments (public policies, plans, programmes or other independent action plans or guidelines undertaken by the local, regional or national governments, communities, non-governmental organizations or companies), in particular the ones that are related with each sustainability theme (e.g. for the local level: local climate change plan; organic food plan for householders; budget savings guidelines for the families).

This information will provide the framework within which to proceed with the comparative evaluation of the results of the assessment based upon the indicators and it will help in mapping the distance to the desired aims and targets.

\subsection{HSC indicators and HSC assessment}

The HSC indicators should be developed according to the results obtained in the previous steps. General indicator selection criteria (e.g. Ott, 1978; Hardi and Zand, 1997) should be taken into account to obtain a consistent and robust indicator set. The indicator system could be structured with two main branches: formal and informal indicators.

Formal indicators are represented by a "technical" set, selected and developed according to general indicator criteria (e.g. heating energy consumption per area or total $\mathrm{CO}_{2}$ emission caused by transport). Informal indicators could follow less rigid procedures but be part of the effort to assess the HSC; such informal indicators

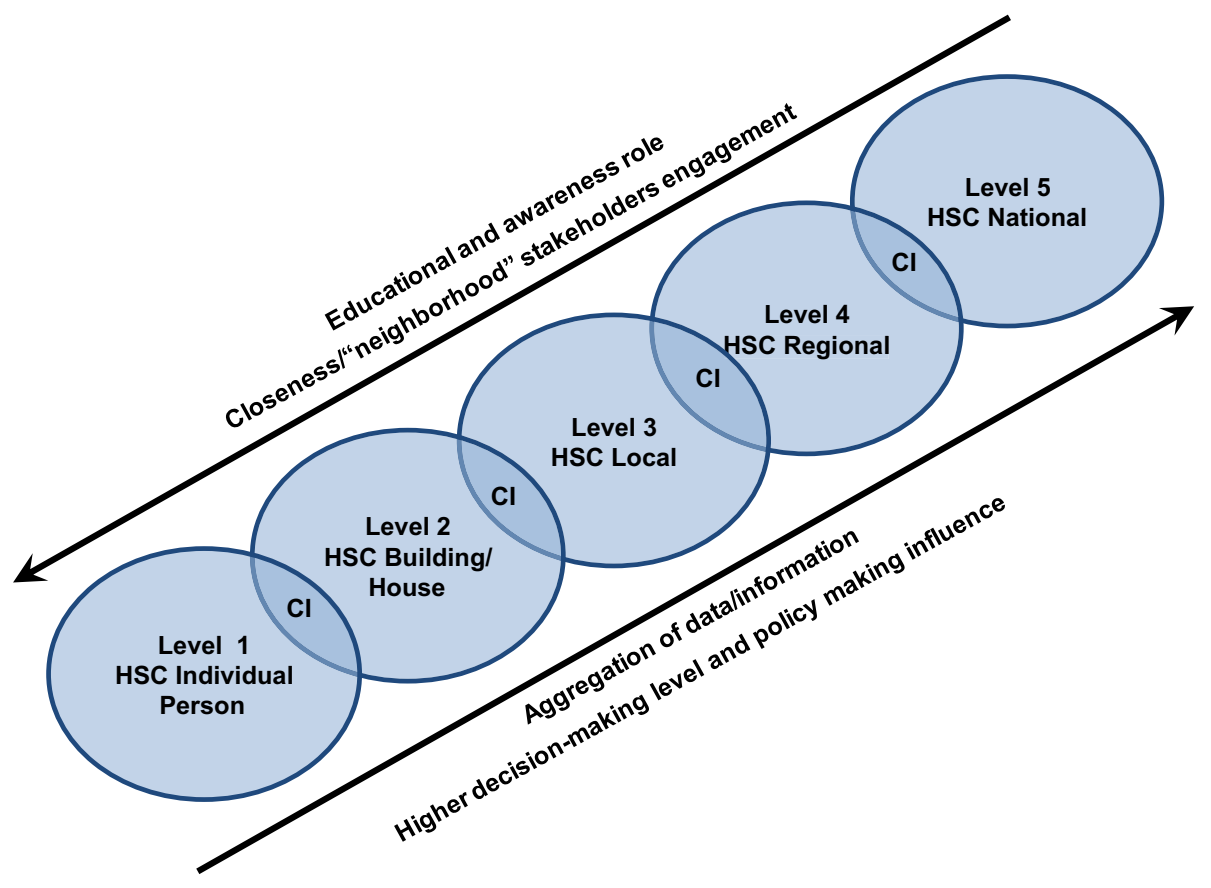

Fig. 3. Cascading interactions among different levels of HSC. 
Table 1

Key-criteria-factors for household SC indicators.

\begin{tabular}{ll}
\hline Key-criteria/factors & Summary of rationale \\
\hline $\begin{array}{c}\text { Strong } \\
\text { sustainability } \\
\text { principles }\end{array}$ & HSC indicator sets should be based on strong \\
& sustainability principles built upon principles of \\
& environmental conservation and involving \\
& decreasing or constant levels of consumption over \\
& time, thus priority should be given to maintenance of \\
& critical levels of Natural Capital (Comim et al., 2007), \\
& and new economics sustainable consumption model \\
& (Ehrenfeld, 2010).
\end{tabular}

Driving forces

HSC is strongly related to driving forces that should be taken into account in the development of the indicator set. The driving forces are, for example technological innovation, level of environmental awareness and concern and environmental protection polices (Zacarias-Farah and Geyer-Allély, 2003; Hobson, 2003; Tukker et al., 2010b)

Integrative domains

Relevancy with family strategic options

Dynamic behaviours, actions and routines

Comparability and robustness
Table 1 (continued)

\begin{tabular}{|c|c|}
\hline Key-criteria/factors & Summary of rationale \\
\hline $\begin{array}{r}\text { Governance and public } \\
\text { participation process }\end{array}$ & $\begin{array}{l}\text { HSC indicator sets should be developed in } \\
\text { accordance with a bottom-up process with emphasis } \\
\text { on public participation, with a weighting procedure } \\
\text { defined by public priorities (Comim et al., 2007). } \\
\text { The European Commission defined five principles of } \\
\text { good governance: "openness, participation, } \\
\text { accountability, effectiveness and coherence," which } \\
\text { are of particular significance in sustainability } \\
\text { assessments. The promotion of dynamic interactions } \\
\text { among all stakeholders should be ensured from the } \\
\text { beginning of the process. It should be supported by } \\
\text { participative and collaborative procedures, where } \\
\text { different actors are empowered to play important } \\
\text { roles, for improving capacity building and assuring } \\
\text { transparency, credibility and robustness, beyond the } \\
\text { strict, predetermined, technical and scientific tasks. } \\
\text { The design, construction, operation and revision of } \\
\text { the indicators should be submitted to a panel of } \\
\text { experts, in accordance with expert consensus } \\
\text { practices, for instance by means of the Delphi } \\
\text { technique. }\end{array}$ \\
\hline $\begin{array}{l}\text { Target audience and } \\
\text { type of language }\end{array}$ & $\begin{array}{l}\text { There should be a clear identification of the types of } \\
\text { target audiences to be reached and the } \\
\text { corresponding preferred language (non-technical) in } \\
\text { the indicator system. The target end-users (residents } \\
\text { or families) and the respective requirements and } \\
\text { realities should be considered in the indicator set } \\
\text { design and operation. It is also essential to give } \\
\text { a clear definition of the central indicator audience, as } \\
\text { it can limit the overall assessment and reporting } \\
\text { structure. }\end{array}$ \\
\hline $\begin{array}{l}\text { Comprehensibility } \\
\text { and communication }\end{array}$ & $\begin{array}{l}\text { The HSC indicators should be comprehensible to the } \\
\text { families and be meaningful and relevant. The } \\
\text { indicators should be easy to communicate to/with } \\
\text { local communities and other local stakeholders (e.g. } \\
\text { local decision-makers, user groups), when working } \\
\text { at the local scale, or with other stakeholders, } \\
\text { depending of the target scale. }\end{array}$ \\
\hline $\begin{array}{l}\text { Relevancy with public } \\
\text { policies and plans }\end{array}$ & $\begin{array}{l}\text { HSC indicator sets should be related with local/ } \\
\text { regional/national and public policies, plans and } \\
\text { programs, including existing sustainability } \\
\text { monitoring initiatives at the national, regional, and } \\
\text { local levels. }\end{array}$ \\
\hline Voluntary indicators & $\begin{array}{l}\text { The adoption of HSC indicators should be } \\
\text { encouraged, because it enhances commitment, } \\
\text { awareness and education of the stakeholders, in } \\
\text { particular residents and families, engaged in the } \\
\text { monitoring process. Such informal signals can } \\
\text { complement the formal indicators provided by } \\
\text { the more traditional technical assessment } \\
\text { procedures. }\end{array}$ \\
\hline $\begin{array}{r}\text { Performance and } \\
\text { benchmarking }\end{array}$ & $\begin{array}{l}\text { HSC indicator sets should be able to demonstrate } \\
\text { differences among households, thereby making } \\
\text { it possible to benchmark performance and to } \\
\text { document 'best practices'. This can also be used to } \\
\text { provide incentives for continuous improvement. }\end{array}$ \\
\hline $\begin{array}{l}\text { Interlink HSC indicators } \\
\text { with environmental } \\
\text { management tools } \\
\text { and certification } \\
\text { processes }\end{array}$ & $\begin{array}{l}\text { HSC indicator sets should be linked with existent } \\
\text { environmental management tools including } \\
\text { certification processes (e.g. sustainable construction, } \\
\text { energy, water, forest). These tools can provide useful } \\
\text { guidance and data for the indicators sets and vice } \\
\text { versa. }\end{array}$ \\
\hline
\end{tabular}

will be put into practice by the residents and will correspond to easy monitoring issues with particular socially relevance to the volunteers. Voluntary indicators can provide high-quality reliable data to supplement the formal evaluation. Areas such as:

a indoor air quality (e.g. household ventilation);

b quality of the water supply (e.g. colour and smell, safety); c healthy eating practices, built upon fresh organic food from the garden; 
d budget saving measures;

e social responsible initiatives (e.g. supply of used clothing or type of goods);

f participation in community initiatives;

$\mathrm{g}$ neighbourhood relationships.

Some authors have addressed the connections between environmental awareness and metering data on household consumption. They underscore the findings that engaging in some symbolic actions play a larger role than other, more environmentally serious consumption practices (Jensen, 2008). The existence of "formal indicators" and "informal/voluntary indicators" can help to ensure the commitment, education and awareness of the residents.

The relationship with existing "external" sustainability indicator systems should be taken into consideration in the selection of the HSC indicators. In Fig. 2, these relationships are synthesized, assuming that other monitoring tools could contribute to the development of HSC indicators, in spite of using different objectives, scopes and approaches. This procedure of maximizing synergies among different initiatives by building upon indicators already in use can help to avoid the proliferation of independent efforts to achieve similar objectives.

Additionally, it should be emphasised that an HSC indicator system will depend significantly upon the primary scale of analysis (Fig. 3). An HSC evaluation at the national level, designed to identify/ support/guide/monitor the performance of a country on this domain will certainly be different from initiatives done at municipal or individual household levels. In fact, the proposed framework and key-criteria/factors (Section 4) should be focused and tailored to each spatial level. Nevertheless, it is fundamental that the HSC indicators that are selected and used should foster dynamic interactions among all spatial levels, through a cascading/cybernetic process. As suggested by Coelho et al. (2010) for the regional SDI scale interaction, this could be achieved through specific indicators (Common Indicators $-\mathrm{CI}$ ), which are relevant for sustainability assessment at different scales. Each CI HSC subset should be established at the national level for all regions, thereby, complementing specific regional indicators, but they should not prevent a region from having its own regional headline HSC indicator set that may correspond entirely or partially to the national headline indicators. On the other hand, using the same framework design, the regional set will define the $\mathrm{CI}$ that should be used at the local level. The same relationship should also be applied at the individual/family level.

The HSC indicators can be aggregated into indices, to reflect the composite results of each HSC domain. The aggregation functions (mathematical or heuristic) could be selected or developed for each particular case. Since there are many different functions with several advantages and disadvantages, this step must be done with special caution to avoid significant losses of information and to ensure meaningful results. The indices or composite indicators should be designed in terms of scope, normalization, aggregation, and validation according to existing guidelines or recommendations, such as the ones presented by Nardo et al. (2005) or Montalvo and Moghayer (2011).

Specific HSC key-criteria/factors for the development and evaluation of indicators should be adopted. This component is a critical step to ensure that the model integrates the singularities and common features of HSC area when compared with other's approaches.

\section{Key-criteria/factors for the practical framework applications}

As emphasised in Section 3, operationalising sustainability measures of consumption is not an easy task. It is strongly influenced by difficulties in clarifying the conceptual meaning of (SC), which in turn are caused by the ambiguities in the notions of sustainable development. In a pragmatic account of SC, many problems remain unaddressed; this makes it difficult to properly formulate and to implement SC indicators. A particular problem for SC lies in its diversity and its domain of application that cannot be universally captured by traditional metrics (Comim et al., 2007). Also, according to Tukker et al. (2010b), there is currently a lack of standardized data sets so that household consumption changes can be more readily monitored across time, geographic areas, and consumer groups. Due to that, a definition of key-criteria/factors and recommendations to support the development of an HSC indicator set are presented in Table 1 .

Therefore, a fundamental step was to use the key-criteria/factors to build the HSC assessment initiatives. These criteria-factors can also be used to evaluate the effectiveness of existing household SC indicator sets. The approach is supported by a checklist of criteria that a household SC indicator system should have, taking into account its scientific background, conceptual coherence and relevance to the SC assessment, indicator organization and methodological approaches for data collection and analysis. Wide-ranging criteria such as being comprehensible and meaningful to the residents or families and having an integrative approach among the different domains of SC, should also be achieved.

In spite of the fact that the proposed key-criteria-factors could be applicable to other sectoral sustainability indicator applications different from HSC, the ones presented are customized to the particular characteristics of the HSC field.

Additionally, broader factors, developed for overall evaluation of sustainability indicator system's performance (Ramos and Caeiro, 2010) could be taken into account in the HSC indicator applications. These may include but not be limited to: cost, sensitivity, quality control, spatial and temporal scales, logistical requirements, understanding and social utility and information management.

\section{Conclusions and recommendations}

In the first part of this article, the authors provided an overview of HSC assessment metrics or related initiatives. The authors analyzed the HSC metrics aims/scope, domains and presented a comparison of methodological approaches for developing and using HSC metrics, including indicator sets. The analyses helped the authors to conclude that most of the available metrics, although using different measurement methods, are focused on only one or two HSC domains and few use systematic indicator sets. Usually, the metrics have not integrated the different sectoral domains of HSC, such as food consumption, housing, personal travel, mobility and tourism; furthermore, most do not integrate the main environmental, social, governance and economic components of HSC, including systemic analyses of the drivers and their effects.

The majority of the assessment metrics and related initiatives were not designed to support effective communication with stakeholders, in particular to non-technical audiences. Most do not foster or support comparisons among approaches to use different metrics. Most do not provide an integrated HSC performance overview because they lack structured monitoring signals about the impacts of family's changes or corrections implemented to achieve more sustainable societal consumption.

This literature review documents that monitoring, assessment, and communication within the HSC area is a very complex and underdeveloped area. Therefore, it is important to develop initiatives to define the main steps, components and criteria to build HSC 
assessment tools based upon indicator sets. To respond to this gap, we developed a methodological approach to build and evaluate the effectiveness of HSC indicators.

The proposed approach integrates several steps from the definition of the HSC scope, dimensions, objectives and targets within the indicator development and assessment process. It is supported by a checklist of objectives that an HSC indicator system should have: i) be easily comprehensible and meaningful to family members, ii) be developed with a bottom-up process with emphasis on public participation and empowerment, iii) use an integrative approach among the different domains, iv) facilitate practical and dynamic behaviours, actions, and routines in implementing HSC, v) provide transparent evaluation of the HSC performance and vi) provide guidance via illustrative best practices and vii) provide financial and non-financial incentives for achieving continuous HSC improvements. The paper highlights the essentiality of providing families with strategic options for responding to external driving forces from governments and from the private sector as well as from the internal, household-specific pressures.
The conceptual framework presented in this paper is to be used as a flexible tool that can be adapted to particular social, political, environmental contexts. While it may not be useful for intercountry comparisons because of specific tailoring, it could be used to measure temporal progress within countries and comparative progress among them. The research team intends to perform follow-up research case studies based upon its usage in diverse HSC contexts. The framework's strengths, weaknesses, effectiveness and usefulness will be tested. Based upon the research results, improvements will be made in the design of the entire framework and of the guiding processes to utilise it.

\section{Acknowledgements}

We would like to acknowledge the valuable collaboration of Ana Lavado in the preliminary stage of this research. The authors would like to express their gratitude for the constructive comments provided by the anonymous reviewers.

\section{Table A1}

A Categorisation of Household Sustainable Consumption (HSC) assessment metrics \& related initiatives according to their aims/scopes, methodologies, domains, scales. Additionally, interpretative comments are provided to help the reader to contextualise the different HSCs assessment metrics.

\begin{tabular}{|c|c|c|c|c|c|}
\hline Author & Name, aims and scope & Methodological aspects & Theme/domain & $\begin{array}{l}\text { Direct use or } \\
\text { development } \\
\text { of indicator } \\
\text { [yes/no] }\end{array}$ & Comments \\
\hline $\begin{array}{l}\text { Baker and Rylatt } \\
\text { (2007) }\end{array}$ & $\begin{array}{l}\text { Prediction of energy } \\
\text { demand. The aim is to use } \\
\text { an approach using } \\
\text { a questionnaire survey, } \\
\text { supported by annual data } \\
\text { and floor-area estimates to } \\
\text { predict how changes in } \\
\text { patterns of usage in } \\
\text { different types of dwelling } \\
\text { can affect energy } \\
\text { consumption which is } \\
\text { important if efforts to } \\
\text { reduce demand and carbon } \\
\text { emissions are to be } \\
\text { effective. }\end{array}$ & $\begin{array}{l}\text { A survey questionnaire based on } \\
\text { the UK National Homes Energy } \\
\text { Rating (NHER) level one survey } \\
\text { form for houses and bungalows was } \\
\text { distributed by post. The data- } \\
\text { analysis procedure included annual } \\
\text { gas and electricity data and floor- } \\
\text { area estimates derived via GIS plus } \\
\text { a two-step clustering technique. }\end{array}$ & Energy & No & $\begin{array}{l}\text { Clusters of higher and lower energy } \\
\text { consumers were discovered and these } \\
\text { were related to indicators of energy } \\
\text { consumption. Although significant } \\
\text { effects of the built-form type were not } \\
\text { observable in the data available, the } \\
\text { effects of related measurable and } \\
\text { countable aspects of form were seen. }\end{array}$ \\
\hline Barr et al. (2005) & $\begin{array}{l}\text { Household waste } \\
\text { management. This paper } \\
\text { examined the structure of } \\
\text { waste reduction, reuse and } \\
\text { recycling behaviour within } \\
\text { the context of wider research } \\
\text { on environmental action in } \\
\text { and around the home. }\end{array}$ & $\begin{array}{l}\text { The strategy was based on previous } \\
\text { work on waste management in } \\
\text { Exeter, England. Using a sample of } \\
1265 \text { households from Devon, } \\
\text { England, the research examined } \\
\text { a range of environmental } \\
\text { behaviours; focussing on energy } \\
\text { saving, water conservation, green } \\
\text { consumerism and waste } \\
\text { management. Using factor analysis, } \\
\text { the data were analyzed to examine } \\
\text { how the different behavioural } \\
\text { variables related to each other. }\end{array}$ & Wastes & No & $\begin{array}{l}\text { An analysis of the frequency of each of } \\
\text { these factorials-defined behaviours } \\
\text { revealed that recycling was still the } \\
\text { activity most practiced by individuals, } \\
\text { with reduction behaviours least } \\
\text { popular. This was explored further by } \\
\text { the use of cluster analysis, which } \\
\text { define four distinctive behavioural } \\
\text { types with different demographic } \\
\text { characteristics. Accordingly, the } \\
\text { research demonstrated that examining } \\
\text { waste management behaviours within } \\
\text { the context of wider environmental } \\
\text { actions could be valuable. }\end{array}$ \\
\hline $\begin{array}{l}\text { Cai and Jiang } \\
\text { (2007) }\end{array}$ & $\begin{array}{l}\text { Comparison in energy } \\
\text { consumption between rural } \\
\text { and urban households in } \\
\text { China. The aim is to confirm } \\
\text { the prediction of the 'ladder } \\
\text { of fuel preferences' theory. }\end{array}$ & $\begin{array}{l}\text { Surveyed the family sizes and } \\
\text { economic statuses, as well as the } \\
\text { types and quantities of energy } \\
\text { consumed from July } 2003 \text { to } \\
\text { October } 2004 \text {. They collected the } \\
\text { data using three methods: pre- } \\
\text { designed questionnaires, } \\
\text { participant observations, } \\
\text { participatory rural appraisals. }\end{array}$ & Energy & No & $\begin{array}{l}\text { Energies used in urban households are } \\
\text { more convenient, cleaner, and more } \\
\text { efficient than those used in rural areas, } \\
\text { where biomass and coal are common } \\
\text { fuels. The amount of energy used for } \\
\text { entertainment and electrical } \\
\text { appliances is greater in urban areas, } \\
\text { whereas the quantity used for cooking } \\
\text { is larger in rural districts. }\end{array}$ \\
\hline
\end{tabular}


Table A1 (continued)

\begin{tabular}{|c|c|c|c|c|c|}
\hline Author & Name, aims and scope & Methodological aspects & Theme/domain & $\begin{array}{l}\text { Direct use or } \\
\text { development } \\
\text { of indicator } \\
\text { [yes/no] }\end{array}$ & Comments \\
\hline CEC (2005) & $\begin{array}{l}\text { Indicators for monitoring } \\
\text { EU Sustainable } \\
\text { Development Strategy. } \\
\text { Eurostat, the European } \\
\text { Commission's statistics office, } \\
\text { has developed a set of } \\
\text { sustainable development } \\
\text { indicators. The indicators are } \\
\text { linked to the EU Sustainable } \\
\text { Development Strategy. }\end{array}$ & $\begin{array}{l}\text { The indicator framework includes } \\
10 \text { themes that reflect major } \\
\text { sustainable development priorities. } \\
\text { Sustainable consumption and } \\
\text { production is one of these themes. } \\
\text { Other indicators of SCP are included } \\
\text { in many of the other themes. } \\
\text { Within this set several indicators } \\
\text { are specific or applicable for } \\
\text { household sustainable } \\
\text { consumption. }\end{array}$ & $\begin{array}{l}\text { Wastes, energy, } \\
\text { expenditures }\end{array}$ & Yes & $\begin{array}{l}\text { The European Commission has other } \\
\text { initiatives about sustainable } \\
\text { consumption and production. These } \\
\text { include initiative on life-cycle based } \\
\text { indicators for sustainable consumption } \\
\text { and production in the European Union } \\
\text { and eco-innovation indicators for } \\
\text { Europe. Furthermore, the European } \\
\text { Environment Agency's Topic Centre is } \\
\text { conducting work for Resource and } \\
\text { Waste Management on a new set of } \\
\text { SCP Indicators for Europe. }\end{array}$ \\
\hline $\begin{array}{l}\text { Chatterjee and } \\
\text { Michelini } \\
\text { (1998) }\end{array}$ & $\begin{array}{l}\text { Household budget } \\
\text { consumption data. The aim } \\
\text { is to use data on expenditures } \\
\text { and incomes of New Zealand } \\
\text { households of different } \\
\text { demographic profiles to } \\
\text { construct equivalence scales. }\end{array}$ & $\begin{array}{l}\text { (i) Extended Linear Expenditure } \\
\text { System; (ii) Data from New Zealand } \\
\text { Household Expenditure and Income } \\
\text { Survey; (iii) Consumption } \\
\text { Equivalence Scales. The survey } \\
\text { target population consisted of } \\
\text { private households living in } \\
\text { permanent dwellings and residing } \\
\text { in New Zealand. The sampling } \\
\text { design used a two-stage selection } \\
\text { method where the first stage } \\
\text { consisted of stratified geographical } \\
\text { areas and the second was a list of } \\
\text { dwellings. }\end{array}$ & $\begin{array}{l}\text { Expenditures } \\
\text { and incomes }\end{array}$ & No & $\begin{array}{l}\text { This was the first attempt at } \\
\text { constructing equivalence scales with } \\
\text { New Zealand household budget data in } \\
\text { the framework of hypothesized utility } \\
\text { maximizing behaviour of households. }\end{array}$ \\
\hline $\begin{array}{l}\text { Curran et al. } \\
\text { (2007) }\end{array}$ & $\begin{array}{l}\text { Household waste disposal. } \\
\text { The aim of the research was } \\
\text { to learn how the residents in } \\
\text { England recycle and reuse } \\
\text { bulky items and to } \\
\text { understand how the } \\
\text { management of these items is } \\
\text { perceived from the point of } \\
\text { view of service users. }\end{array}$ & $\begin{array}{l}\text { British researchers performed } \\
\text { a survey of a } 1450 \text { households in } 3 \\
\text { areas of England, in order to assess } \\
\text { the collection and reuse rate of } \\
\text { bulky items in England. }\end{array}$ & Wastes & No & $\begin{array}{l}\text { The researchers concluded that for } \\
\text { effective and efficient waste } \\
\text { management, it is important to } \\
\text { understand the public perception of } \\
\text { convenience. The residents are globally } \\
\text { satisfied with the national waste } \\
\text { management schemes but they think } \\
\text { this service should be free of charge }\end{array}$ \\
\hline $\begin{array}{l}\text { Dahlén et al. } \\
\text { (2009) }\end{array}$ & $\begin{array}{l}\text { Household waste } \\
\text { management pathways. The } \\
\text { aim was to provide policy } \\
\text { makers and waste } \\
\text { management planners with } \\
\text { information about how } \\
\text { recycling programs affect the } \\
\text { quantities of specific } \\
\text { materials recycled and/or } \\
\text { managed in other ways. }\end{array}$ & $\begin{array}{l}\text { Compiling waste collection data } \\
\text { annual recycling reports from local } \\
\text { authorities. A number of different } \\
\text { waste collection methods were } \\
\text { included in the study. Waste } \\
\text { management professionals were } \\
\text { interviewed regarding the design of } \\
\text { the collection system and collection } \\
\text { results. }\end{array}$ & Wastes & No & $\begin{array}{l}\text { Sixteen sources of error in official } \\
\text { waste statistics were identified and the } \\
\text { results of the study emphasize the } \\
\text { importance of reliable waste } \\
\text { generation and composition data to } \\
\text { underpin waste management policies. }\end{array}$ \\
\hline $\begin{array}{l}\text { Delgado and } \\
\text { Miles (1997) }\end{array}$ & $\begin{array}{l}\text { Household characteristics } \\
\text { and consumption } \\
\text { behaviour. Application of } \\
\text { nonparametric methods in } \\
\text { order to evaluate empirical } \\
\text { aspects of household } \\
\text { consumption behaviours. }\end{array}$ & $\begin{array}{l}\text { First, study the differences in the } \\
\text { consumption behaviour between } \\
\text { household types. Secondly, derive } \\
\text { the functional form for the food } \\
\text { Engel curve; using specification } \\
\text { tests consisted in the direction of } \\
\text { nonparametric alternatives. Finally, } \\
\text { use this specification to discuss } \\
\text { misleading conclusions. }\end{array}$ & $\begin{array}{l}\text { Household } \\
\text { characteristics } \\
\text { (goods, food, } \\
\text { alcohol, cloth, } \\
\text { domestic fuel, } \\
\text { transport, } \\
\text { recreation, } \\
\text { non-durables) }\end{array}$ & No & $\begin{array}{l}\text { Except for food, consumption } \\
\text { behaviour is not significantly affected } \\
\text { by changes in the household } \\
\text { characteristics. }\end{array}$ \\
\hline $\begin{array}{l}\text { Delgado et al. } \\
\quad(2007)\end{array}$ & $\begin{array}{l}\text { Analysis of household } \\
\text { hazardous waste (HHW). The } \\
\text { aim of this work was to } \\
\text { determine the dynamics of } \\
\text { solid waste generation and to } \\
\text { be able to compare the results } \\
\text { of two regions, regarding } \\
\text { consumption patterns and } \\
\text { solid waste generation rates. }\end{array}$ & $\begin{array}{l}\text { In two regions of Mexico household } \\
\text { solid waste was analyzed } \\
\text { quantitatively. In order to perform } \\
\text { this analysis, the population was } \\
\text { categorized into three } \\
\text { socioeconomic strata (lower, } \\
\text { middle, upper). The work was } \\
\text { carried out in four phases: } 1 \text { ) } \\
\text { Selection of sampling areas } \\
\text { according to income range of the } \\
\text { households; } 2 \text { ) Survey study to }\end{array}$ & Wastes & No & $\begin{array}{l}\text { The study demonstrated that the } \\
\text { production of HHW is independent of } \\
\text { income level. Furthermore, the } \\
\text { composition of the solid waste stream } \\
\text { in both regions suggested the influence } \\
\text { of another set of variables such as local } \\
\text { climate, migration patterns and } \\
\text { marketing coverage. Further research } \\
\text { is needed in order to establish the } \\
\text { effect of low quantities of HHW upon } \\
\text { the environment and public health. }\end{array}$ \\
\hline
\end{tabular}

determine socioeconomic

parameters; 3) Solid waste generation analysis; 4) Hazardous waste characterization. 
Table A1 (continued)

\begin{tabular}{|c|c|c|}
\hline Author & Name, aims and scope & Methodological aspects \\
\hline $\begin{array}{l}\text { Druckman and } \\
\text { Jackson (2008) }\end{array}$ & $\begin{array}{l}\text { Household energy } \\
\text { consumption and } \mathbf{C O}_{2} \\
\text { emissions. Exploration of the } \\
\text { patterns of UK household } \\
\text { energy use and associated } \\
\text { carbon emissions at national } \\
\text { level and also at high levels of } \\
\text { socioeconomic and } \\
\text { geographical disaggregation }\end{array}$ & $\begin{array}{l}\text { Local Area Resource Analysis } \\
\text { (LARA) and Output Area } \\
\text { Classification (OAC). Examination of } \\
\text { specific neighborhoods with } \\
\text { contrasting levels of deprivation, } \\
\text { and typical 'types' of UK. } \\
\text { households based on } \\
\text { socioeconomic characteristics. }\end{array}$ \\
\hline $\begin{array}{l}\text { Druckman and } \\
\text { Jackson (2009) }\end{array}$ & $\begin{array}{l}\text { Carbon Footprint. The } \\
\text { authors present a socio- } \\
\text { economically, disaggregated } \\
\text { framework for attributing } \\
\mathrm{CO}_{2} \text { emissions to people's } \\
\text { high level functional needs. }\end{array}$ & $\begin{array}{l}\text { Quasi-Multi-Regional Input } \\
\text {-Output (QMRIO) Model: takes into } \\
\text { account all } \mathrm{CO}_{2} \text { emissions that arise } \\
\text { from energy used in production of } \\
\text { goods and services to satisfy UK } \\
\text { household demand, whether the } \\
\text { emissions occur in the UK or } \\
\text { abroad. }\end{array}$ \\
\hline
\end{tabular}

Druckman et al.

(2008)

EEA (2011)

Fahy and Davies (2007)

Ferrer-i-

Carbonell and

Van Den Bergh

(2004)
Geographically and socioeconomically household consumption model. This paper presented an approach to household consumption modelling in which the material demands of small socio-economically homogeneous neighborhoods are estimated on the basis of consumer expenditure data in conjunction with census data

EEA household

consumption indicators. The

EEA list eight $\mathrm{HC}$ indicators and fact sheets within Europe's environment
Household waste arising is estimated through incorporation of a household metabolism model. Local Area Resource Analysis (LARA) model and census data.
The eight indicators are 1.

Expenditure on personal mobility;

2. Municipal waste generation; 3 . Household energy consumption; 4. Penetration of environmentally friendly products; 5 . Household number and size; 6. Drinking Water Quality; 7. Urban wastewater treatment; 8 . Household expenditure categories. The European Environmental Agency assesses the temporal evolution of these indicators in Europe and discusses the European goals and policies.

The study was conducted with approximately 2000 participants and involved a survey, interviews with selected participants and focus groups with young people in order to understand their perceptions of waste. The final phase consisted in a household waste exercise with a selected group of participants lasting one month.

Econometric and empirical analysis of household consumption. Relationships between different types of household expenditures and a range of household characteristics are assessed. The data used to estimate the models are from the Budget Survey by Statistics Netherlands.

$\begin{array}{ll}\text { Theme/domain } & \begin{array}{l}\text { Direct use or Comments } \\ \text { development } \\ \text { of indicator } \\ \text { [yes/no] }\end{array}\end{array}$

Energy; carbon No

emissions

It is shown that household energy use and associated carbon emissions are both strongly, but not solely, related to income levels. Other factors, such as type of dwelling, tenure, household consumption and rural/urban location are also extremely important.
$\mathrm{CO}_{2}$ emissions Yes

Wastes

No

Energy, water, Yes wastewater,

waste,

household type, expenditure,

green

products

Wastes

No

Expenditures

No
$\mathrm{CO}_{2}$ emissions attributable to households were 15\% above 1990 levels in 2004, and that although absolute decoupling occurred between household expenditure and $\mathrm{CO}_{2}$ during the UK's switch from coal to gas in the early 1990's, since then only slight relative decoupling is evident. The proportion of $\mathrm{CO}_{2}$ that arises outside UK borders in support of UK consumption is rising, and reducing these emissions is particularly problematic in a global trading system. The study relies on the census data which has a 10-year interval, revealing a static throughout the study period; the use of linear regression to estimate values for 2001 when the conversion values were anomalous; in the model it used an average expenditure to physical unit conversion values for all items within one commodity category.

This list of indicators are included in the EEA indicators about Europe's environment available in the website of EEA and are assessed with different data sets. decision making. The study presents a first econometric analysis of consumption in the context of environmental sustainability 
Table A1 (continued)

\begin{tabular}{|c|c|c|c|c|c|}
\hline Author & Name, aims and scope & Methodological aspects & Theme/domain & $\begin{array}{l}\text { Direct use or } \\
\text { development } \\
\text { of indicator } \\
\text { [yes/no] }\end{array}$ & Comments \\
\hline Firth et al. (2008) & $\begin{array}{l}\text { Household electricity } \\
\text { consumption trends. } \\
\text { Monitoring study of the } \\
\text { electricity of a sample of UK } \\
\text { domestic buildings. }\end{array}$ & $\begin{array}{l}\text { Five minutely average whole house } \\
\text { power consumption was recorded } \\
\text { for } 72 \text { dwellings at five sites over } \\
\text { a } 2 \text {-year monitoring period. Five- } \\
\text { minutely average values of PV } \\
\text { system electricity generation, } \\
\text { import of electricity from the grid } \\
\text { and export of electricity to the grid } \\
\text { were recorded by current and } \\
\text { voltage sensors and pulsed output } \\
\text { metres. Data were collected using } \\
\text { loggers installed in a number of the } \\
\text { homes and was downloaded on } \\
\text { a regular basis via the public } \\
\text { telephone network. The data } \\
\text { loggers had a constant power draw } \\
\text { of } 10 \text { W and this power } \\
\text { consumption was subtracted from } \\
\text { the recorded household power } \\
\text { consumption where necessary. The } \\
\text { monitoring systems were funded } \\
\text { by the UK Department of Trade and } \\
\text { Industry under the PV Domestic } \\
\text { Field Trial Programme and the } \\
\text { energy consultants for the sites } \\
\text { were Energy for Sustainable } \\
\text { Development Ltd. }\end{array}$ & Energy & No & $\begin{array}{l}\text { The overall increase in electricity } \\
\text { consumption is attributed to a } 10.2 \% \\
\text { increase in the consumption of } \\
\text { 'standby' appliances and a } 4.7 \% \\
\text { increase in the consumption of 'active' } \\
\text { appliances. The consumption of } \\
\text { different energy user groups was also } \\
\text { investigated and low and high users } \\
\text { are identified as contributing to the } \\
\text { overall increase in consumption. The } \\
\text { need for further investigation, such as } \\
\text { quantitative and qualitative studies, to } \\
\text { improve understanding in domestic } \\
\text { electricity consumption is discussed. }\end{array}$ \\
\hline $\begin{array}{c}\text { Gatersleben } \\
\text { (2001) }\end{array}$ & $\begin{array}{l}\text { Sustainable household } \\
\text { consumption and quality of } \\
\text { life. This study examined how } \\
\text { people judge the } \\
\text { sustainability (quality-of-life } \\
\text { effects) of sustainable } \\
\text { household consumption } \\
\text { patterns (less energy-use } \\
\text { demanding) and associated } \\
\text { policy options. }\end{array}$ & $\begin{array}{l}\text { A multidisciplinary computer- } \\
\text { based field study among } 393 \text { Dutch } \\
\text { Households. }\end{array}$ & $\begin{array}{l}\text { Quality of life, } \\
\text { energy }\end{array}$ & No & $\begin{array}{l}\text { Respondents did appear to be more } \\
\text { willing to pay for sustaining their } \\
\text { comfort, freedom and pleasure while } \\
\text { reducing the environmental impact of } \\
\text { their consumption than they were to } \\
\text { give up some of their quality of life. }\end{array}$ \\
\hline $\begin{array}{l}\text { Gilg and Barr } \\
\text { (2006) }\end{array}$ & $\begin{array}{l}\text { Water Saving Behaviour. The } \\
\text { main goal of this research was } \\
\text { to examine the links between } \\
\text { water saving, energy } \\
\text { conservation, green } \\
\text { consumerism and waste } \\
\text { management in and around } \\
\text { the home. }\end{array}$ & $\begin{array}{l}\text { British researchers examined the } \\
\text { social, attitudinal and behavioural } \\
\text { composition of water saving } \\
\text { activities using a sample of } 1600 \\
\text { households from Devon (UK). The } \\
\text { authors used a 14-page } \\
\text { questionnaire that asked a series of } \\
\text { questions about "environmental } \\
\text { habits" and that included } \\
\text { a frequency scale. }\end{array}$ & Water & No & $\begin{array}{l}\text { The authors have identified four } \\
\text { different types of individuals according } \\
\text { to their behavioural characteristics, } \\
\text { from committed environmentalist to } \\
\text { non-environmentalist. The authors } \\
\text { concluded that it is necessary to } \\
\text { recognize behavioural complexity in } \\
\text { order to ensure that policies and } \\
\text { initiatives for water conservation are } \\
\text { effective. }\end{array}$ \\
\hline $\begin{array}{l}\text { Gram-Hanssen } \\
\quad(2008)\end{array}$ & $\begin{array}{l}\text { Consuming Routines. } \\
\text { Knowledge of how routines } \\
\text { develop and change is } \\
\text { extremely relevant from an } \\
\text { SC perspective. }\end{array}$ & $\begin{array}{l}\text { Interviews survey sent to } \\
\text { homeowners. The main question } \\
\text { was to what extent routines are } \\
\text { influenced by the social or the } \\
\text { cultural structures of society, } \\
\text { including both norms } \\
\text { unconsciously carried from } \\
\text { childhood, as well as influences } \\
\text { from present technology or } \\
\text { individual reflection. }\end{array}$ & Energy & No & $\begin{array}{l}\text { Routines are investigated from three } \\
\text { different perspectives: a historical } \\
\text { perspective of how new technologies } \\
\text { have entered homes, a consumer } \\
\text { perspective of how both houses and } \\
\text { new technologies are purchased and } \\
\text { a user perspective of how routines } \\
\text { develop while these technologies are } \\
\text { being used. This study helps to } \\
\text { understand why energy labels do not } \\
\text { necessarily provide households with } \\
\text { the right incentives to renovate their } \\
\text { homes. }\end{array}$ \\
\hline $\begin{array}{r}\text { Gram-Hanssen } \\
\text { et al. (2007) }\end{array}$ & $\begin{array}{l}\text { Energy Labels on Buildings. } \\
\text { Understand if energy labels } \\
\text { on households provide the } \\
\text { homeowners with good } \\
\text { incentives to reduce their } \\
\text { energy consumption. }\end{array}$ & $\begin{array}{l}\text { Qualitative, in-depth interviews } \\
\text { and surveys with } 10 \text { households in } \\
\text { Denmark and } 10 \text { households in } \\
\text { Belgium. }\end{array}$ & Energy & No & $\begin{array}{l}\text { The survey shows that personal } \\
\text { contact and oral communication with } \\
\text { the expert enhances trust in the } \\
\text { labelling system and means the label is } \\
\text { better understood. Performing similar } \\
\text { studies in other countries would } \\
\text { consolidate the results of their } \\
\text { investigation. }\end{array}$ \\
\hline
\end{tabular}


Table A1 (continued)

\begin{tabular}{|c|c|c|c|c|c|}
\hline Author & Name, aims and scope & Methodological aspects & Theme/domain & $\begin{array}{l}\text { Direct use or } \\
\text { development } \\
\text { of indicator } \\
\text { [yes/no] }\end{array}$ & Comments \\
\hline GrØnhØj (2006) & $\begin{array}{l}\text { Consumer Practices and } \\
\text { Behaviour. The study used } \\
\text { qualitative research methods } \\
\text { to examine family member } \\
\text { interactions in relation to four } \\
\text { topics: organic food, water } \\
\text { and energy, waste and } \\
\text { transport. }\end{array}$ & $\begin{array}{l}\text { Qualitative Interviews. One } \\
\text { hundred families with children } \\
\text { were randomly chosen from the } \\
\text { local telephone directory and } \\
\text { screened by means of telephone } \\
\text { interviews. The aim of this was to } \\
\text { recruit informants representative of } \\
\text { Danish families in terms of } \\
\text { socioeconomic background and } \\
\text { environmentally oriented } \\
\text { consumption habits. In the } \\
\text { qualitative interviews, short } \\
\text { descriptions of hypothetical choice } \\
\text { situations were applied. When } \\
\text { using this method, informants were } \\
\text { encouraged to respond to } \\
\text { a description of a situation in } \\
\text { a specific, everyday, easily } \\
\text { recognisable context. }\end{array}$ & $\begin{array}{l}\text { Food, water and } \\
\text { energy, wastes, } \\
\text { transport }\end{array}$ & No & $\begin{array}{l}\text { Many green consumer practices } \\
\text { involve several family members, who } \\
\text { may be able to exert significant } \\
\text { influences on household subscription } \\
\text { to these practices. Assessing past } \\
\text { instances of talks or discussions in } \\
\text { a family is not an easy task. }\end{array}$ \\
\hline Hal (2007) & $\begin{array}{l}\text { Sustainable Building; } \\
\text { Sustainable Housing; } \\
\text { Labelling System. The aim is } \\
\text { to prove that sustainable } \\
\text { building is not more } \\
\text { expensive than standard } \\
\text { building practice. }\end{array}$ & $\begin{array}{l}\text { Labelling system with } 8 \text { points of } \\
\text { incentives: an overall quality test } \\
\text { for housing to make quality } \\
\text { a controllable element of the price } \\
\text { negotiations; green mortgage, } \\
\text { climate mortgage; discount on } \\
\text { (property) tax; integration in the } \\
\text { Dutch Funda System; private law } \\
\text { agreements between the developer } \\
\text { and a municipality; objective }\end{array}$ & Energy & No & $\begin{array}{l}\text { The research showed that the positive } \\
\text { financial aspects are hardly ever used } \\
\text { to promote sustainable building. } \\
\text { Recommendation to give priority to } \\
\text { the introduction of a labelling system } \\
\text { that translates sustainability in } \\
\text { housing into a manageable and } \\
\text { controllable system, this one should } \\
\text { clearly identify the level of } \\
\text { sustainability of a specific house. }\end{array}$ \\
\hline
\end{tabular}

standards in a design competition; development of affordable and green innovative housing concepts; a green rebuild fund.

Halme et al. Sustainability evaluation of The sustainable evaluation method (2006) European household services. Evaluation of household home services that contribute to at least two of the three dimensions of sustainable development: environment, social aspects and economy.

Hobson (2003) Household consumption practices. This article's focus is on the importance of the consideration of how individuals read and react to $\mathrm{SC}$ information.

Holden (2004) Towards sustainable consumption: do green households have smaller ecological footprints? This research describes how the study team compared the ecological footprints of "green" and "ordinary" households.

Jensen (2008) Household Consumption: Measures and Patterns. Discussion of the connection between environmental awareness and metering data on household consumption, how families' understanding of environmental awareness and environmental practices relates to their overall household consumption. used with participants of the linkages between lifestyle and was based on a set of indicators

Material use, energy, water, wastes, space use, emissions

Questionnaire and interviews were a sustainable behaviour change program called Action at Home, using Giddens' theory

The footprint calculations are based on a number of consumption categories that have severe environmental consequences, such as energy and material use in the home, and transport. The comparison is based on a survey of 404 households in the city of Stavanger, where 66 respondents were members of the

Environmental Home Guard in Norway.

The main intention was to combine maps of social segregation in the city with maps of segregation in consumption in order to illustrate consumption. The research has generally been based on an "everyday-consumption" approach, in combination with an exhaustive use of household consumption data, as well as lifestyle indicators and building data.
Energy, water, wastes, transport and shopping

Energy, materials, Yes transport

Energy, water
It appears that the social effects of the assessed services are larger than their environmental and economic benefits.

Giddens' theory that leads to the creation of a framework which emphasizes the importance of 'known' and 'local' information, as well as discursive processes.

The analysis suggests that, even if the green households have a smaller ecological footprint per household member, this is not caused by their participation in the Home Guard. It merely reflects the fact that green households are larger than ordinary households.

It is argued that the social structures underlying consumption and green behaviour should be recognized in the formulation of environmental policies, and that instead of using sustainable practices such as 'environmental awareness' as a sales argument, more reflexive strategies that take consumers' preferences into account should be considered. 
Table A1 (continued)

\begin{tabular}{cll}
\hline Author & Name, aims and scope & Methodological aspects \\
& & \\
\hline $\begin{array}{c}\text { Katz-Gerro and } \\
\text { Talmud (2005) }\end{array}$ & $\begin{array}{l}\text { Consumption Patterns of } \\
\text { Household Expenditures. } \\
\text { The paper proposed a new } \\
\text { analysis of consumption } \\
\text { inequality using relational } \\
\text { methods, derived from } \\
\text { network images of social } \\
\text { structure. }\end{array}$ & $\begin{array}{l}\text { Combination of the structural } \\
\text { analysis with theoretical concerns } \\
\text { in consumer research to propose } \\
\text { a relational theory of consumption } \\
\text { space, to construct a stratification } \\
\text { indicator, and to demonstrate its } \\
\text { analytical efficacy with aggregate } \\
\text { consumption data. Statistical }\end{array}$ \\
&
\end{tabular}

Kerkhof et al. (2009a)

Kerkhof et al. (2009b)

Larsen (2009)

Lins et al. (2002)
Comparison between and within countries in household emissions. The aim was to identify determinants of national household $\mathrm{CO}_{2}$ emissions of households in the

Netherlands, the UK, Sweden, Norway, around 2000.

Relationship between Household Expenditures and the Environmental Impact Categories.

Evaluation of the relationships between household expenditures and the environmental impact categories: climate change, acidification, eutrophication and smog formation. product groups purchased by Dutch consumers, expenditure data and environmental impact per consumer

A hybrid approach of process analysis and input-output analysis with data on Household Expenditures, was used.

$\mathrm{CO}_{2}$ emissions No

Expenditures

No

Derives a variance-minimizing, unbiased estimator by first estimating and inverting Engel curves; then combining the estimators from the inverted Engel curves.

The basic model is based on linear relationship between electricity consumption in each surveyed

household and the ownership of several appliances. The paper applies the new technique known as Conditional Demand Analysis (CDA) to estimate consumption of appliances. consumption appliance in use in Brazil
Direct use or development of indicator

[yes/no]

Expenditures Yes

First, analysis should look at relational patterns between consumption groups in a more empirically refined way, using notions of social topology of consumption space, structural equivalence, and a system of codetermination. Second, due to data limitation, the authors did not differentiate between individual-level and household-level consumption patterns. Third, the vertical consumption vector should be tested vis-à-vis various life outcomes to establish its validity as a compound indicator of social inequality. Forth, further analyses should explore the ways to which role equivalence recovers the existence of social strata, as manifested on aggregate consumption data, and also examines the ways to which statistical classifications of both social units and consumption categories affect vertical and horizontal dimensions of social hierarchy.

A comparison of the national results at the product level points out that country characteristics, like energy supply, population density and the availability of district heating, influence variation in household $\mathrm{CO}_{2}$ emissions between and within countries.

The environmental impact increases with increasing household expenditures, although the degree to which the environmental impact increases differs per impact category. Climate change and eutrophication increase less than proportionally with increasing expenditures. Acidification increases nearly proportionally with increasing expenditures, whereas smog formation increases more than proportionally. It appears that the mix of necessities and luxuries to which an environmental impact is related is essential in explaining the relationships.

This article demonstrates how it is possible to improve upon current practice in estimating total household consumption expenditure.

$$
\text { consumption expenditure. }
$$

\author{
They address the need of considering \\ not only appliance ownership but also \\ specific regional consumption \\ differences, when dealing with \\ forecasting and planning. Information \\ given by conditional demand analysis \\ is valuable in forecasting future \\ regional energy and power demands, \\ as well as planning future electrical \\ generating capacity.
}

(continued on next page) 
Table A1 (continued)

\begin{tabular}{|c|c|c|c|c|c|}
\hline Author & Name, aims and scope & Methodological aspects & Theme/domain & $\begin{array}{l}\text { Direct use or } \\
\text { development } \\
\text { of indicator } \\
\text { [yes/no] }\end{array}$ & Comments \\
\hline $\begin{array}{l}\text { Löfström and } \\
\text { Palm (2008) }\end{array}$ & $\begin{array}{l}\text { Household Energy Use. The } \\
\text { aim is to discuss three } \\
\text { different methods for } \\
\text { visualizing energy use. }\end{array}$ & $\begin{array}{l}\text { Three different ways of seeking to } \\
\text { raise awareness: energy advice } \\
\text { directed to households, keeping } \\
\text { time-diaries to visualize energy- } \\
\text { related behaviour and, as an } \\
\text { example of a technical solution, the } \\
\text { 'Power-Award Cord'. }\end{array}$ & Energy & No & $\begin{array}{l}\text { Each method has its pros and cons, bu } \\
\text { combining different methods could } \\
\text { prove to be a useful way to draw } \\
\text { attention to household energy use and } \\
\text { the possibilities for energy reduction. } \\
\text { By combining the data gained from the } \\
\text { different methods, it will be more } \\
\text { likely that strategies will be found tha } \\
\text { are better suited to people's behaviour }\end{array}$ \\
\hline $\begin{array}{l}\text { Lorek and } \\
\text { Spangenberg } \\
\text { (2001), } \\
\text { Spangenberg } \\
\text { and Lorek } \\
(2002)\end{array}$ & $\begin{array}{l}\text { Indicator for } \\
\text { environmentally } \\
\text { sustainable household } \\
\text { consumption. The objective } \\
\text { of this work was to identify } \\
\text { those areas of consumption in } \\
\text { which private households can } \\
\text { make significant } \\
\text { contributions to } \\
\text { environmental sustainability, } \\
\text { and to present a transparent } \\
\text { and comprehensive set of } \\
\text { indicators for them. }\end{array}$ & $\begin{array}{l}\text { First the authors had to establish } \\
\text { a new basic concept of household } \\
\text { consumption indicators. As } \\
\text { a second step, a set of indicators for } \\
\text { sustainable household } \\
\text { consumption was derived, based on } \\
\text { a new, actor-centred approach. The } \\
\text { proposal presented is based on } \\
\text { calculations of resource } \\
\text { consumption as the key driving } \\
\text { force of current environmental } \\
\text { problems, and an estimate of actors' } \\
\text { influence. The limited and thus } \\
\text { easily communicable number of } \\
\text { indicators results from the } \\
\text { identification of dominating factors } \\
\text { of resource consumption, which are } \\
\text { covered by one or a few indicators } \\
\text { each. A final } 14 \text { indicator sets are } \\
\text { proposed. }\end{array}$ & $\begin{array}{l}\text { Construction and } \\
\text { housing, food, } \\
\text { transport }\end{array}$ & & $\begin{array}{l}\text { Households identified three } \\
\text { consumption clusters as priority fields } \\
\text { for action: construction and housing, } \\
\text { food/nutrition and transport (in this } \\
\text { order). All other consumption clusters } \\
\text { can be considered environmentally } \\
\text { marginal, providing combined saving } \\
\text { potentials of less than } 10 \% \text { of the total } \\
\text { resource consumption. From } \\
\text { a description of the respective roles of } \\
\text { actors based on anecdotal evidence, } \\
\text { a semi-quantitative 'actor matrix' is } \\
\text { presented, indicating the relative } \\
\text { influence of different actors in each } \\
\text { consumption cluster. According to the } \\
\text { authors it is possible to adapt the } \\
\text { system of indicators to the diversity o } \\
\text { country size infrastructure, climate, } \\
\text { heating, etc. }\end{array}$ \\
\hline
\end{tabular}

Márquez et al. (2008)

Moll et al. (2005) Household Energ

Metabolism. This concept was applied to analyzing consumption patterns and to identifying possibilities for the development of sustainable household consumption patterns
Munksgaard et al. Environmental Pressure of (2005) Consumption. It shows how the input-output approach can be used to enumerate the problems of SC.
Nansai et al.

(2007)

\section{A simple indicator for} sustainable consumption: Classifying goods and services into three types to determine the optimal consumption patterns of Japanese households. i) Sampling procedure; ii) Likert scale development; iii) application of data mining techniques. The householders were selected using non-random sampling, working on only with those who agreed to participate at every stage of the study.

Household metabolism was determined in terms of total energy requirements (production, distribution, consumption and waste processing), including both direct and indirect energy requirements, using a hybrid method (process analysis + input -output analysis). This method enables us to evaluate various determinants of the environmental load of consumption consistently at several levels.

Input-output analysis and Data

Envelopment Analysis (DEA). Based on a literature survey the authors present measures of the emissions of carbon dioxide at different spatial levels. Further, the authors take more environmental effects into account and introduce the concept of environmental efficiency by combining input-output modelling and data envelopment analysis

The optimal consumption patterns were calculated using a linear programming model, taking into account different environmental burdens to be minimized: energy consumption, $\mathrm{CO}_{2}$ emissions, wastes and $\mathrm{NO}_{\mathrm{x}}$ emissions.
Wastes

No

$\mathrm{CO}_{2}$ consumption $\mathrm{No}$ and emissions; energy

Good and services, energy, $\mathrm{CO}_{2}$ emissions, wastes, $\mathrm{NO}_{\mathrm{x}}$ emissions.
The elements identified on each rule indicate that socioeconomic strata are important factors, related to behavioural attributes and consumption habits; the main relationship is based on attributes of waste generation.

Analyses of different types of households are important for providing a basis for options to induce decreases of the environmental load of household consumption. The identification of determining factors that affect change is helpful for governmental, economic and institutional actors in designing approaches and policies aiming at a decrease in the environmental load of household consumption.

It was demonstrated that input -output modelling has a wide range of life-cycle oriented applications when combined with other data sources such as detailed trade statistics, foreign input-output and environmental statistics, and household expenditure data.

Each type of commodity was characterized from the viewpoint of economic and Environmental properties. The results can be applied to identify the commodity types of various commodities in daily life. 
Table A1 (continued)

\begin{tabular}{|c|c|c|c|c|c|}
\hline Author & Name, aims and scope & Methodological aspects & Theme/domain & $\begin{array}{l}\text { Direct use or } \\
\text { development } \\
\text { of indicator } \\
\text { [yes/no] }\end{array}$ & Comments \\
\hline $\begin{array}{l}\text { Noorman and } \\
\text { Kamminga } \\
(1998)\end{array}$ & $\begin{array}{l}\text { Indirect Energy Use of } \\
\text { Households. The research } \\
\text { explores potential } \\
\text { relationships between } \\
\text { a substantial energy taxes - } \\
\text { subsidy scheme directed at } \\
\text { manufactures and the } \\
\text { indirect energy use of Dutch } \\
\text { households. }\end{array}$ & $\begin{array}{l}\text { Energy intensities derived from } \\
\text { input-output analyses and } \\
\text { financial data from input-output } \\
\text { tables. Data collection from Dutch } \\
\text { National Accounts. }\end{array}$ & $\begin{array}{l}\text { Energy, } \mathrm{CO}_{2} \\
\text { emissions }\end{array}$ & No & $\begin{array}{l}\text { Two important issues were not } \\
\text { addressed: the assumption that the } \\
\text { physical output of sectors will not } \\
\text { change does not seem to be very } \\
\text { realistic and the effect of such } \\
\text { economic issues as transaction costs on } \\
\text { the reimbursement of the tax revenues } \\
\text { and the issue of early depreciation of } \\
\text { the technology currently used have not } \\
\text { been considered. These two aspects } \\
\text { may have a negative impact on the } \\
\text { energy conservation potential } \\
\text { calculated in this article. }\end{array}$ \\
\hline OECD (1999) & $\begin{array}{l}\text { Household Sustainable } \\
\text { Consumption indicators. } \\
\text { This report is one of the } \\
\text { products of the OECD work } \\
\text { program on environmental } \\
\text { indicators and supports the } \\
\text { OECD work program on } \\
\text { sustainable consumption. } \\
\text { Several sets of household } \\
\text { consumption patterns } \\
\text { indicators are listed: an OECD } \\
\text { Core Set of environmental } \\
\text { indicators that is common to }\end{array}$ & $\begin{array}{l}\text { The framework adopted structure } \\
\text { household consumption indicators } \\
\text { resembles of other OECD work on } \\
\text { sectoral indicators. It is based on an } \\
\text { adjusted PSR model and } \\
\text { distinguishes three themes: i) } \\
\text { environmentally significant } \\
\text { consumption trends and pattern; ii) } \\
\text { interactions between consumption } \\
\text { patterns and the environment; iii) } \\
\text { economic and policy aspects. }\end{array}$ & $\begin{array}{l}\text { Transport and } \\
\text { communication, } \\
\text { Goods, Energy, } \\
\text { water, Recreation } \\
\text { and tourism }\end{array}$ & Yes & $\begin{array}{l}\text { This work highlights the interactions } \\
\text { between household consumption } \\
\text { patterns and environmental issues, } \\
\text { and provides one of the building blocks } \\
\text { for sustainable development } \\
\text { indicators. The indicators cover major } \\
\text { economic and socio-demographic } \\
\text { trends, and key household } \\
\text { consumption trends having an } \\
\text { environmental significance. The } \\
\text { indicators systems is centred in the } \\
\text { environmental dimensional of } \\
\text { sustainability. }\end{array}$ \\
\hline
\end{tabular}

various sets of indicators to integrate environmental concerns in sectoral policies (e.g. energy, transport and agriculture)

OECD (2001) Household Food Consumption. The OECD Sector Case Study on

Household Food Consumption presents the key results from the national case studies and the separate study on methodologies and indicators for estimating household environmental impact from household food consumption.

Ojeda-Benítez et al. (2008)

Solid waste

characterization. The objective of this research was to learn about the composition and quantity of solid waste generated by family typology.
Survey of composition and generation rate of household wastes. This paper presents the results of a survey on household waste generation and composition in Beijing, China. Sample communities were selected by the integration of five indices including family population, income, age and education.
The study used the needsopportunity-ability model of consumer behaviour, Cumulative energy requirements analysis, Input-output analysis, Hybrid analysis, Life Cycle Assessment, Ecological footprint, Ecological rucksack, Material-flux analysis, Transport related methods

This research was divided in two phases: the first entailed a sample identification and selection process aimed at obtaining a representative group of suburbs or Basic Geostatistical Areas (AGEB) involving the three socioeconomic strata detailed above. The second stage of this project corresponded to RSW waste characterization and quantification. This phase required Residential Solid Waste (RSW) collection and analysis of field data as well as the design and layout of a work area where collected solid waste samples were characterized and quantified.

i) Determination of samples; ii) implementing the survey; iii) weighing and recording. The survey envisaged covering 113 households. To ensure the representativeness of samples, the selected households were geographically scattered and of different socioeconomic levels.
Food, direct/ Yes indirect environmental impacts from households food consumption patterns (energy, waste generation, transport, greenhouse gas emissions, air and water pollution) Wastes

Wastes 
Table A1 (continued)

\begin{tabular}{|c|c|c|c|c|c|}
\hline Author & Name, aims and scope & Methodological aspects & Theme/domain & $\begin{array}{l}\text { Direct use or } \\
\text { development } \\
\text { of indicator } \\
\text { [yes/no] }\end{array}$ & Comments \\
\hline Sardianou (2007) & $\begin{array}{l}\text { Energy Conservation } \\
\text { Framework for Greece. } \\
\text { Development of an empirical } \\
\text { model to investigate the main } \\
\text { determinants of household } \\
\text { energy conservation patterns } \\
\text { in Greece employment cross- } \\
\text { section data. }\end{array}$ & $\begin{array}{l}\text { In the Empirical Analysis, } \\
\text { household energy-conserving } \\
\text { choice models were employed, } \\
\text { using a discrete and a latent trait } \\
\text { variable respectively as } \\
\text { a dependent variable. }\end{array}$ & Energy & No & $\begin{array}{l}\text { The results show that socioeconomic } \\
\text { variables are suitable to explain } \\
\text { differences towards energy } \\
\text { conservation preferences, they also } \\
\text { suggest that electricity expenditures } \\
\text { and age of the respondent are } \\
\text { negatively associated with the number } \\
\text { of energy-conserving actions that } \\
\text { a consumer is willing to adopt. }\end{array}$ \\
\hline Saunders (1979) & $\begin{array}{l}\text { Concept of Total Household } \\
\text { Consumption. The author } \\
\text { showed how far figures of } \\
\text { total household consumption } \\
\text { and its division between } \\
\text { collective and private } \\
\text { consumption, can, in fact, be }\end{array}$ & $\begin{array}{l}\text { The authors measure total } \\
\text { household consumption based on } \\
\text { collective and private consumption } \\
\text { based on ICP database. By } \\
\text { expenditure on public services, } \\
\text { governments provide many goods } \\
\text { and services, which are alternatives }\end{array}$ & Expenditures & No & $\begin{array}{l}\text { The method is rarely used explicitly in } \\
\text { Western national accounts, one reason } \\
\text { is the slow progress in the analysis by } \\
\text { purpose of government expenditure, } \\
\text { and the other is the incomplete data } \\
\text { provided by national accounting } \\
\text { statistics. }\end{array}$ \\
\hline
\end{tabular}

derived, for the advanced countries, from the data expenditures on consumption. The combination of the two has obvious of National Accounts, supplemented by the International Comparison Project (ICP).

Schenkel et al. Household Consumption

(2005) (HC) Structure. The aim is to specifically consider the effect of the enlargement of markets, resulting from the process of transition in Central and Eastern European countries, on the structure of household consumption.

\section{Scholderer and Grunert (2005)}

Sujauddin et al (2008)

\section{behaviour and}

Consumption. A model is developed that synthesizes two theoretical frameworks approaches - the household production and the convenience orientation, assuming that the influence of resource constraints on actual convenience behaviours is doubly mediated, first by perceptions of resources constrains, and then by convenience orientations.

\section{Household solid waste} characterization and management. This study adequately showed that household solid waste can be converted from burden to resource through segregation at the source, since people are aware of their role in this direction provided a mechanism to assist them in this pursuit exists and the burden is distributed according to the amount of waste generated.
The study involved a structured questionnaire and encompassed 75 households from five different socioeconomic groups: low, lower middle, middle, upper middle and high. Wastes, collected from all the groups of households, were segregated and weighed.
Expenditures

No

Food

No

Wastes

No

Between 1995 and 1999 there was certainly a change in the consumption patterns in Eastern European Countries. However, it is not possible to say with certainty whether this process has already come to an end, nor, if it were to continue, what the outcome will be, particularly in respect of the budget shares in real time.

All effects of perceived resources constraints on store choice and product choice were completely mediated by consumers' convenience orientations. The relationship between objective and perceived resources is rather more complex than often assumed. 
Table A1 (continued)

\begin{tabular}{|c|c|c|}
\hline Author & Name, aims and scope & Methodological aspects \\
\hline $\begin{array}{l}\text { Sutcliffe et al. } \\
\quad(2008)\end{array}$ & $\begin{array}{l}\text { Ecological Footprint } \\
\text { Analysis (EFA). The study } \\
\text { aims to test whether there is } \\
\text { scope to use EFA to see } \\
\text { whether it can be used to } \\
\text { encourage changes in } \\
\text { behaviour towards less } \\
\text { resource intensive lifestyles. }\end{array}$ & $\begin{array}{l}\text { Four Questionnaire and Ecological } \\
\text { Footprint Analysis at household } \\
\text { level were used. Eighteen } \\
\text { households completed a sequence } \\
\text { of four questionnaires over a three- } \\
\text { month period. They were provided } \\
\text { with a mini-report to read between } \\
\text { questionnaires two and three, } \\
\text { which linked global overshoot to } \\
\text { individuals' lifestyles. }\end{array}$ \\
\hline $\begin{array}{c}\text { Takase et al. } \\
\text { (2005) }\end{array}$ & $\begin{array}{l}\text { Household Sustainable } \\
\text { Consumption Patterns. } \\
\text { Estimation of direct and } \\
\text { indirect emission loads } \\
\text { induced by household } \\
\text { consumption according to the } \\
\text { WIO model }\end{array}$ & $\begin{array}{l}\text { Waste Input-Output (WIO) model, } \\
\text { based on goods and services } \\
\text { producing sectors, waste-treatment } \\
\text { sectors, waste types and waste } \\
\text { generation coefficients at Japanese } \\
\text { household's }\end{array}$ \\
\hline UN/DESA (1998) & $\begin{array}{l}\text { Measuring changes in } \\
\text { consumption and } \\
\text { production (SCP) patterns. } \\
\text { The United Nations } \\
\text { Department of Economic and } \\
\text { Social Affairs (UN/DESA) } \\
\text { published a set of indicators } \\
\text { as an important element of } \\
\text { United Nations Commission } \\
\text { on Sustainable Development } \\
\text { (CSD) work programme of } \\
\text { indicators for sustainable } \\
\text { development. }\end{array}$ & $\begin{array}{l}\text { The set of indicators is the outcome } \\
\text { of consultations and workshops } \\
\text { with policy makers and experts on } \\
\text { SCP and indicators of sustainable } \\
\text { development. } 17 \text { SCP indicators are } \\
\text { selected as a core set, covering } 4 \text { key } \\
\text { resources and } 5 \text { consumption } \\
\text { clusters. Within this set several } \\
\text { indicators are specific or applicable } \\
\text { for household sustainable } \\
\text { consumption. }\end{array}$ \\
\hline $\begin{array}{l}\text { Van den Bergh } \\
\quad(2008)\end{array}$ & $\begin{array}{l}\text { Effectiveness of } \\
\text { Environmental Regulation } \\
\text { of Household Behavior. To } \\
\text { overcome the lack of a firm } \\
\text { empirical basis, economic } \\
\text { studies in } 3 \text { areas of } \\
\text { environmentally relevant } \\
\text { activities of households were } \\
\text { reviewed: residential use of } \\
\text { energy, generation of solid } \\
\text { waste and recycling, and } \\
\text { residential use of water. }\end{array}$ & $\begin{array}{l}\text { Econometric and Empirical Studies. } \\
\text { Next to price and income } \\
\text { elasticities, attention was devoted } \\
\text { to individual socioeconomic } \\
\text { features and psychological factors, } \\
\text { such as attitudes, knowledge, } \\
\text { perceptions and values. }\end{array}$ \\
\hline $\begin{array}{l}\text { Wiedmann et al. } \\
\text { (2005) }\end{array}$ & $\begin{array}{l}\text { Ecological Footprint (EF). } \\
\text { Presentation of a method that } \\
\text { allows the disaggregation of } \\
\text { UK EF by economic sector, } \\
\text { detailed final demand } \\
\text { category, sub-national area or } \\
\text { socioeconomic groups } \\
\text { including households }\end{array}$ & $\begin{array}{l}\text { Combination of National Footprint } \\
\text { Accounts with monetary Input } \\
\text { - Output Analysis. This method } \\
\text { allows the disaggregation of } \\
\text { existing national footprint } \\
\text { estimates by economic sector, final } \\
\text { demand category, sub-national } \\
\text { area, or socioeconomic groups } \\
\text { while ensuring full comparability of } \\
\text { results. It also may help to extend } \\
\text { the potential application of EF } \\
\text { concept to inform policies and } \\
\text { strategies on SC. The method } \\
\text { involves seven steps: } 1 \text { - associate } \\
\text { NFA EF of production and imports } \\
\text { with industrial sectors; } 2 \text { - prepare } \\
\text { combined supply matrix; } \\
3 \text { - prepare combined use matrix in } \\
\text { basic prices; } 4 \text { - calculate direct } \\
\text { and indirect requirement matrix; } \\
5 \text { - calculate direct and indirect } \\
\text { intensity vectors; } 6 \text { - calculate } \\
\text { EF of final demand categories; } \\
7 \text { - disaggregate final demand } \\
\text { categories }\end{array}$ \\
\hline
\end{tabular}

$\begin{array}{ll}\text { Theme/domain } & \begin{array}{l}\text { Direct use or Comments } \\ \text { development } \\ \text { of indicator } \\ \text { [yes/no] }\end{array}\end{array}$

[yes/no]

Food and energy, Yes $\quad$ EFA aggregates a range of individual transport, house consumption and waste components and garden and converts them into the biosize, waste, expenditures productive land area required to support this activity. The results show that EFA can be used at household level to encourage changes in behaviour towards less resource intensive lifestyles.

$\mathrm{CO}_{2}$ emissions; $\quad$ No Waste

Energy, materials, Yes water, land,

mobility,

consumer goods

and services,

building and

housekeeping,

food, recreation

Energy, wastes, water

Food, energy, Yes catering services and transport
The model is applied to some typical SC scenarios: shifting transportation modes, the longer use of household electric appliances, and less cooking at home. The income rebound effects should be considered to evaluate environmental loads induced by different consumption patterns. UN/DESA is currently in the process of revising this publication to reflect new priorities and emerging key issues on SCP, for example, impact of consumption and production patterns on climate change, recycling rate of material, waste from life-cycle of products, institutional capacity in shifting towards SCP, and others.

There are a few empirical studies that systematically combine socioeconomic and psychological determinants. A range of insights for environmental policy is derived, and research recommendations are offered. -output analysis to re-allocate existing Footprint accounts. This extends the potential for applications of the EF concept and helps to inform scenarios, policies and strategies on SC. The method can be applied to every country for witch National Footprint Account exists and where appropriate economic and environmental accounts are available. Nevertheless the input -output approach is exclusively based on monetary flux between the 76 industrial sectors studied, and does not take into account that actual physical flows of materials and energy. 
Table A1 (continued)

\begin{tabular}{|c|c|c|c|c|c|}
\hline Author & Name, aims and scope & Methodological aspects & Theme/domain & $\begin{array}{l}\text { Direct use or } \\
\text { development } \\
\text { of indicator } \\
\text { [yes/no] }\end{array}$ & Comments \\
\hline $\begin{array}{l}\text { Wood and } \\
\text { Newborough } \\
(2003)\end{array}$ & $\begin{array}{l}\text { Energy indicators for } \\
\text { domestic appliances. The } \\
\text { paper presents the findings of } \\
\text { a UK field study involving } \\
\text { households which considered } \\
\text { domestic cooking: it } \\
\text { compares the effectiveness of } \\
\text { providing paper-based } \\
\text { energy use/saving } \\
\text { information with electronic } \\
\text { feedback of energy } \\
\text { consumption via Energy- } \\
\text { Consumption Indicators (ECI) } \\
\text { designed specifically for this } \\
\text { investigation. }\end{array}$ & $\begin{array}{l}\text { An Energy-Consumption Indicators } \\
\text { (ECI) display unit was design } \\
\text { indicating five LCD displays of } \\
\text { energy consumption (this event, } \\
\text { this week, last week, today and } \\
\text { yesterday). The ECI display was } \\
\text { connected at each sampled home } \\
\text { and derived from a current } \\
\text { transformer, which was attached to } \\
\text { the main supply cable to an } \\
\text { electronic cooker. Twelve Control } \\
\text { Group households (a total of } 44 \text { ) } \\
\text { were monitored for a period of at } \\
\text { least } 12 \text { months. Some of the groups } \\
\text { received feedback others received } \\
\text { bills as normal. }\end{array}$ & Energy & Yes & $\begin{array}{l}\text { The associated behavioural changes } \\
\text { and the importance of providing } \\
\text { regular feedback during use were } \\
\text { identified. It is recommended that } \\
\text { further attention be given to } \\
\text { optimizing the design and assessing } \\
\text { the use of energy consumption } \\
\text { indicators in the home, in order to } \\
\text { maximize the associated energy- } \\
\text { saving potential. }\end{array}$ \\
\hline $\begin{array}{l}\text { Zacarias-Farah } \\
\text { and Geyer- } \\
\text { Allély (2003) }\end{array}$ & $\begin{array}{l}\text { Household Consumption } \\
\text { Patterns. This research } \\
\text { presents key facts and figures } \\
\text { from OECD Environment's } \\
\text { Directorate's 1999-2000 } \\
\text { Programme on Sustainable } \\
\text { Consumption, which } \\
\text { provided new data and } \\
\text { analysis on household } \\
\text { consumption trends and } \\
\text { government policy to } \\
\text { promote more SC patterns. }\end{array}$ & $\begin{array}{l}\text { Analysis of statistics from OECD } \\
\text { Environment's Directorate's } 1999 \\
-2000 \text { Programme on Sustainable } \\
\text { Consumption }\end{array}$ & $\begin{array}{l}\text { Energy, Wastes, } \\
\text { tourism travel }\end{array}$ & No & $\begin{array}{l}\text { It shows that environmental impacts } \\
\text { from trends in household tourism } \\
\text { travel, energy consumption and waste } \\
\text { generation will increase, and also } \\
\text { identifies some of the most important } \\
\text { driving forces behind household } \\
\text { consumptions patterns. This discussion } \\
\text { of consumer decision-making and } \\
\text { specific drivers of household } \\
\text { consumption suggests a broad web of } \\
\text { influences on consumer choices, } \\
\text { including for environmentally friendly } \\
\text { purchases and behaviours. }\end{array}$ \\
\hline Zhou et al. (2008) & $\begin{array}{l}\text { Sustainable development of } \\
\text { rural households energy. } \\
\text { Review the evolution of the } \\
\text { rural household energy } \\
\text { consumption structure in } \\
\text { northern China from } 1996 \text { to } \\
2005 \text {. }\end{array}$ & $\begin{array}{l}\text { Review of rural household Energy } \\
\text { Consumption Statistical Yearbook } \\
\text { of China (1996-1995) and } \\
\text { Statistical Yearbook of China } \\
(1996-2005) \text {. }\end{array}$ & Energy & No & $\begin{array}{l}\text { Some countermeasures were } \\
\text { suggested to overcome the obstacles } \\
\text { involved in the sustainable } \\
\text { development of rural household } \\
\text { energy in northern China, from energy } \\
\text { resources to sociopolitical policies. }\end{array}$ \\
\hline
\end{tabular}

\section{References}

Alcott, B., 2005. Jevons' paradox. Ecol. Econ. 54 (1), 9-21.

Baker, K.J.R., Rylatt, M., 2007. Improving the prediction of UK domestic energydemand using annual consumption-data. Appl. Energy 85, 475-482.

Barr, S., Gilg, A., Ford, N., 2005. Defining the multi-dimensional aspects of household waste management: a study of reported behaviour in Devon. Resour. Conserv. Recyl. 45, 172-192.

Brown, H.S., Vergragt, P.J., 2008. Bounded socio-technical experiments as agents of systemic change: the case of a zero-energy residential building. Technol. Forecast Soc. 75, 107-130.

Cai, J., Jiang, Z., 2007. Changing of energy consumption patterns from rural households to urban households in China: an example from Shaanxi Province, China. Renew. Sust. Energ. Rev. 12, 1667-1680.

CEC, 2005. Sustainable Development Indicators to monitor the implementation of the EU Sustainable Development Strategy. Commission of the European Communities CEC, Brussels. SEC (2005) 161 Final.

Chatterjee, S., Michelini, C., 1998. Household consumption equivalence scales: some estimates from New Zealand household expenditure and income survey data. Aust. New Zeal. J. Stat. 40 (2), 141-150.

Clark, G., 2007. Evolution of the global sustainable consumption and production policy and the United Nations Environment Programme's (UNEP) supporting activities. J. Cleaner Prod. 15, 492-498.

Coelho, P., Mascarenhas, A., Vaz, P., Dores, A., Ramos, T.B., 2010. A framework for regional sustainability assessment: developing indicators for a Portuguese region. Sustain. Dev. 18 (4), 211-219.

Cohen, M., Brown, H., Vergragt, P.J., 2010. Individual consumption and systemic societal transformation: introduction to the special issue. Sustain. Sci. Prac. Policy 6 (2), 6-12.

COM, 16.7.2008. Communication from the Commission to the European Parliament the Council, the European Economic and Social Committee and the Committee of the Regions on the Sustainable Consumption and Production and Sustainable Industrial Policy Action Plan. EUROPEAN Commission, Brussels. 397.

Comim, F., Tsutsumi, R., Varea, A., 2007. Choosing sustainable consumption: a capability perspective on indicators. J. Int. Dev. 19, 493-509.

Curran, A., William, I., Heaven, S., 2007. Management of household bulky waste in England. Resour. Conserv. Recyl. 51, 78-92.
Dahlén, L., Åberg, H., Lagerkvist, A., Berg, P.E.O., 2009. Inconsistent pathways of household waste. Waste Manage. 29 (6), 1798-1806.

Delgado, M., Miles, D., 1997. Household characteristics and consumption behaviour: a nonparametric approach. Empirical Econ. 22, 409-429.

Delgado, O.B., Ojeda-Benítez, S., Márquez-Benavides, L., 2007. Comparative analysis of hazardous household waste in two Mexican regions. Waste Manage. 27, 792-801.

Druckman, A., Jackson, T., 2008. Household energy consumption in the UK: a highly geographically and socio-economically disaggregated model. Energ. Policy 36, 3177-3192.

Druckman, A., Jackson, T., 2009. The carbon footprint of UK households 1990-2004 a socio-economically disaggregated, quasi-multi-regional input-output model. Ecol. Econ. 68, 2066-2077.

Druckman, A., Jackson, T., Sinclair, P., 2008. A geographically and socio-economically disaggregated local household consumption model for the UK. J. Cleaner Prod. $16,870-880$.

EEA, 2005. Household Consumption and the Environment Report $n^{\circ} 11$, Copenhagen.

EEA, 2010. The European Environment State and Outlook 2010. In: Consumption and the Environment. European Environment Agency, Copenhagen.

EEA, 2011. Indicators and Fact Sheets about Europe's Environment. Household Consumption Indicators. http://www.eea.europa.eu/data-and-maps/ indicators $\# \mathrm{c} 7=\mathrm{all} \& \mathrm{c} 5=$ households $\& \mathrm{c} 0=10 \& \mathrm{~b} \leq \mathrm{start}=0$ (accessed 10.03.11.)

EEA and ETC/SCP, 2010. Database and Project Using National Accounts Matrices with Environmental Accounts (NAMEA) Based Input-output Methodology. European Environment Agency and European Topic Centre on Sustainable Consumption and Production.

Ehrenfeld, J.R., 2010. Book reviews. The new economics of sustainable consumption. Seeds of change, by Gill Seyfang and edited by David Elliot. J. Ind. Ecol. 14 (1) 169-171.

Fahy, F., Davies, A., 2007. Home improvements: household waste minimisation and action research. Resour. Conserv. Recyl. 52, 13-27.

Ferrer-i-Carbonell, A., Van Den Bergh, J., 2004. A micro-econometric analysis of determinants of unsustainable consumption in the Netherlands. Environ. Resour. Econ. 27, 367-389.

Firth, S., Lomas, K., Wright, A., Wall, R., 2008. Identifying trends in the use of domestic appliances from household electricity consumption measurements. Energ. Build. 40, 926-936. 
Gatersleben, B., 2001. Sustainable household consumption and quality of life: the acceptability of sustainable consumption patterns and consumer policy strategies. Int. J. Environ. Pollut. 15 (2), 200-216.

Gilg, A., Barr, S., 2006. Behavioural attitudes to water saving. Evidence from a study of environmental actions. Ecol. Econ. 57 (3), 400-414.

Girod, B., Haan, P., 2009. GHG reduction potential of changes in consumption patterns and higher quality levels from Swiss household consumption survey. Energ. Policy 37 (12), 5650-5661.

Gram-Hanssen, K., 2008. Consuming technologies - developing routines. J. Cleaner Prod. 16, 1181-1189.

Gram-Hanssen, K., Bartiaux, F., Jensen, M., Cantaert, M., 2007. Do homeowners use energy labels? A comparison between Denmark and Belgium. Energ. Policy 35, 2879-2888.

GrØnhØj, A., 2006. Communication about consumption: a family process perspective on 'green' consumer practices. J. Consum. Behav. 5, 491-503.

Hal, J.D.M., 2007. A labeling system as stepping stone for incentives related to the profitability of sustainable housing. J. Hous. Built Environ. 22, 393-408.

Halme, M., Anttonen, M., Hrauda, G., Kortman, J., 2006. Sustainability evaluation of European household services. J. Cleaner Prod. 14, 1529-1540.

Hardi, P., Zand, T., 1997. Assessing Sustainable Development: Principles in Practice. International Institute of Sustainable Development, Canada, Winnipeg.

Hobson, K., 2003. Thinking habits into action: the role of knowledge and process in questioning household consumption practices. Local Environ. 8 (1), 95-112.

Holden, E., 2004. Towards sustainable consumption: do green households have smaller ecological footprints? Int. J. Sustainable Dev. 7 (1), 44-58.

Huijbregts, M.A.J., Hellweg, S., Frischknecht, R., 2008. Ecological footprint accounting in the life cycle assessment of products. Ecol. Econ. 64, 798-807.

Jackson, T., 2007. Sustainable consumption. In: Atkinson, G., Dietz, S., Neumayer, E. (Eds.), Handbook of Sustainable Development. Edward Elgar Publishing Limited, UK.

Jackson, T., 2009. Prosperity Without Growth: The Transition to a Sustainable Economy. Earth Scan, London. Sterling, VA

Jensen, O., 2008. Measuring consumption in households: interpretations and strategies. Ecol. Econ. 68, 353-361.

Katz-Gerro, T., Talmud, I., 2005. Structural analysis of a consumption-based stratification indicator: relational proximity of household expenditures. Soc. Indic Res. 73, 109-132.

Kerkhof, A.C., Benders, RM.J., Moll, H.C., 2009a. Determinants of variation in household $\mathrm{CO}_{2}$ emissions between and within countries. Energ. Policy 37, 1509-1517.

Kerkhof, A.C., Nonhebel, S., Moll, H.C., 2009 b. Relating the environmental impact of consumption to household expenditures: an input-output analysis. Ecol. Econ. $68,1160-1170$.

Kletzan, D., Koppl, A., Kratena, K., Schleicher, S., Wuger, M., 2002. Modeling Sustainable Consumption. From theoretical concepts to policy guidelines. Empirica 29, 131-144.

Larsen, E.R., 2009. Using inverted Engel curves to estimate material standards of living in a household. Empirical Econ. 36, 109-132.

Lins, M.P.E., Silva, A.C.M., Rosa, L.P., 2002. Regional variations in energy consumption of appliances: conditional demand analysis applied to Brazilian households. Ann. Oper. Res. 117, 235-246.

Löfström, E., Palm, J., 2008. Visualising household energy use in the interest of developing sustainable energy systems. Hous. Stud. 23 (6), 935-940.

Lorek, S., Spangenberg, J.H., 2001. Indicators for environmentally sustainable household consumption. Int. J. Sustainable Dev. 4 (1), 101-120.

Márquez, M.Y., Ojeda, S., Hidalgo, H., 2008. Identification of behavior patterns in household solid waste generation in Mexicali's city: study case. Resour. Conserv. Recyl. 52 (11), 1299-1306.

Moll, H.C., Noorman, K., Kok, R., Engström, R., Throne-Holst, H., Clak, C., 2005. Pursuing more sustainable consumption by analysing household metabolism in European countries and cities. J. Ind. Ecol. 9 (1-2), 259-275.

Montalvo, C., Moghayer, S.M., 2011. State of an Innovation System: Theoretical and Empirical Advances towards and Innovation Efficiency Index Delft, TNO Working paper series, 2011-002.

Munksgaard, J., Wier, M., Lenzen, M., Dey, C., 2005. Using input-output analysis to measure the environmental pressure of consumption at different spatial levels. J. Ind. Ecol. 9 (1-2), 169-185.

Nansai, K., Kagawa, S., Moriguchi, Y., 2007. Proposal of a simple indicator for sustainable consumption: classifying goods and services into three types focusing on their optimal consumption levels. J. Cleaner Prod. 15, 879-885.

Nardo, M., Saisana, M., Saltelli, A., Tarantola, S., 2005. Tools for Composite Indicators Building Join Research Center. Institute for the Protection and Security of the Citizen Econometrics and Statistical Support to Antifraud Unit European Commission, EUR 21682 EN, Italy.

Noorman, K.J., Kamminga, K.J., 1998. Reducing residential energy use for a sustainable future: fossil fuel taxation as a tool to reduce energy demand and related $\mathrm{CO}_{2}$ emissions of Dutch households. Sustainable Dev. 6 (3), 143-153.

OECD, 1997. Sustainable Consumption and Production. Organization for Cooperation and Development, Paris, Paris.

OECD, 1999. Towards more Sustainable Household Consumption Patterns Indicators to Measure Progress Environment Directorate. Environment Policy Committee. Working Group on the State of the Environment. ENV/EPOC/SE(98)2/FINAL
OECD, 2001. Sustainable Consumption: Sector Case Study Series. Household Food Consumption: Trends, Environmental Impacts and Policy Responses Working Party on National Environmental Policy. Environment Directorate. Environment Policy Committee. Organisation for Co-operation and Development. ENV/EPOC/ WPNEP(2001)13/FINAL.

Organization for Co-operation and Development (OECD), 2002. Towards Sustainable Household Consumption? Trends and Policies in OECD Countries. Organization for Co-operation and Development, Paris.

OECD, 2008a. Household Behaviour and the Environment. Reviewing the Evidence. Organization for Co-operation and Development, Paris.

OECD, 2008b. Promoting Sustainable Consumption. Good Practices in OECD Countries. Organization for Co-operation and Development, Paris.

Ojeda-Benítez, S., Armijo-de Veja, S.C.A., Marquez-Montenegro, Y., 2008. Household solid waste characterization by family socioeconomic profile as unit of analysis. Resour. Conserv. Recyl. 52, 992-999.

Ott, W.R., 1978. Environmental Indices - Theory and Practice. Michigan, Ann Harbor Science.

Polimeni, J.M., Mayumi, K., Giampietro, M., Alcott, B., 2008. The Jevons Paradox and the Myth of Resource Efficiency Improvements. Earthscan Research Editions, London, Sterling VA.

Qu, X., Li, Z., Xie, X., Sui, Y., Yang, L., Chen, Y., 2009. Survey of composition and generation rate of household wastes in Beijing, China. Waste Manage. 29, $2618-2624$

Ramos, T.B., 2009. Development of regional sustainability indicators and the role of academia in this process: the Portuguese practice. J. Cleaner Prod. 17, $1101-1115$.

Ramos, T.B., Caeiro, S., 2010. Meta-performance evaluation of sustainability indicators. Ecol. Indic 10, 157-166.

Sardianou, E., 2007. Estimating energy conservation patterns of Greek Households. Energ. Policy 35, 3778-3791.

Saunders, C., 1979. Measures of total household consumption. In: Review of Income \& Wealth. Blackwell Publishing Limited, pp. 351-366.

Schenkel, M., Sturam, D., Occari, F., 2005. Between transition and enlargement: the composition of consumption in European households. Transit. Stud. Rev. 12 (1), 58-73.

Schneider, F., Kallis, G., Martinez-Alier, J., 2010. Crisis or opportunity? Economic degrowth for social equity and ecological sustainability. Introduction to this special issue. J. Cleaner Prod. 18, 511-518.

Scholderer, J., Grunert, K.G., 2005. Consumers, food and convenience: the long way from resource constraints to actual consumption patterns. J. Econ. Psychol. 26, 105-128.

Scipioni, A., Mazzi, A., Zuliani, F., Mason, M., 2008. The ISO 14031 standard to guide the urban sustainability measurement process: an Italian experience. J. Cleaner Prod. 16, 1247-1257.

Spangenberg, J.H., Lorek, S., 2002. Environmentally sustainable household consumption: from aggregate environmental pressures to priority fields of action. Ecol. Econ. 43 (2-3), 127-140.

Sujauddin, M., Huda, S.M.S., Hoque, R.A.T.M., 2008. Household solid waste characteristics and management in Chittagong, Bangladesh. Waste Manage. 28 (9), 1688-1695.

Sutcliffe, M., Hooper, P., Howell, R., 2008. Can eco-footprinting analysis e used successfully to encourage more sustainable behaviour at the household level? Sustainable Dev. 16, 1-16.

Takase, K., Kondo, Y., Washizu, A., 2005. An analysis of sustainable consumption by the waste input-output model. J. Ind. Ecol. 9 (2), 201-219.

Tukker, A., Cohen, M.J., Hubacek, K., Mont, O., 2010a. Sustainable consumption and production. J. Ind. Ecol. 14 (1), 1-3.

Tukker, A., Cohen, M.J., Hubacek, K., Mont, O., 2010b. The impacts of household consumption and options for change. J. Ind. Ecol. 14 (1), 13-30.

UNDESA/UNEP, 2010. Proposed input to csd 18 and 19 on a 10-year framework of programmes on SC and production (10YFP ON SCP). Revised Draft (7 April 2010). Document prepared by the Marrakech Process Secretariat: UNDESA and UNEP.

UNEP, 2011. Paving the Way for Sustainable Consumption and Production. The Marrakech Process Progress Report. Towards a 10 Year Framework of Programmes on Sustainable Consumption and Production. DTI/1394/PA. United Nations Environment Programme, Paris, France.

United Nations Department of Economic and Social Affairs - UN/DESA, 1998. Measuring Changes in Consumption and Production Patterns: A Set of Indicators, Population Division, New York.

Van den Bergh, 2008. Environmental regulation of households: an empirical review of economic and psychological factors. Ecol. Econ. 66, 559-574.

Wiedmann, T., Minx, J., Barrett, J., Wackernagel, M., 2005. Allocating ecological footprints to final consumption categories with input-output analysis. Ecol. Econ. 56, 28-48.

Wood, G., Newborough, M., 2003. Dynamic energy-consumption indicators for domestic appliances: environment, behaviour and design. Energ. Build. 35, 821-841.

Zacarias-Farah, A., Geyer-Allély, E., 2003. Household consumption patterns in OECD countries: trends and figures. J. Cleaner Prod. 11, 819-827.

Zhou, Z., Wu, W., Chen, Q., Chen, S., 2008. Study on sustainable development of rural household energy in northern China. Resour. Conserv. Recyl. 12, 2227-2239. 